\title{
Bio-Engineered Concrete: A Critical Review on The Next Generation of Durable Concrete
}

\author{
Md. Fahad Shahriar Zawad, Md. Asifur Rahman*, Sudipto Nath Priyom \\ Department of Civil Engineering, Chittagong University of Engineering \& Technology (CUET), Chattogram-4349, BANGLADESH \\ Kaptai, Highway Raozan Pahartali Rd, Chattogram-4349 \\ ${ }^{*}$ Corresponding authors: u1501011@student.cuet.ac.bd
}

SUBMITTED 16 April 2021 REVISED 18 May 2021 ACCEPTED 24 June 2021

\begin{abstract}
Concrete is a prerequisite material for infrastructural development, which is required to be sufficiently strong and durable. It consists of fine, coarse, and aggregate particles bonded with a fluid cement that hardens over time. However, micro cracks development in concrete is a significant threat to its durability. To overcome this issue, several treatments and maintenance methods are adopted after construction, to ensure the durability of the structure. These include the use of bio-engineered concrete, which involved the biochemical reaction of non-reacted limestone and a calcium-based nutrient with the help of bacteria. These bio-cultures (bacteria) act as spores, which have the ability to survive up to 200 years, as they are also found to start the mineralization process and the filling of cracks or pores when in contact with moisture. Previous research proved that bio-engineered concrete is a self-healing technology, which developed the mechanical strength properties of the composite materials. The mechanism and healing process of the concrete is also natural and eco-friendly. Therefore, this study aims to critically analyze bio-engineered concrete and its future potentials in the Structural Engineering field, through the use of literature review. The data analysis was conducted in order to provide gradual and informative ideas on the historical background, present situation, and main mechanism process of the materials. According to the literature review, bioengineered concrete has a promising outcome in the case of strength increment and crack healing. However, the only disadvantage was its less application in the practical fields. The results concluded that bio-engineered concrete is a new method for ensuring sustainable infrastructural development. And also, it indicated that more practical outcome-based analysis with extensive application in various aspects should be conducted, in order to assess the overall durability.
\end{abstract}

KEYWORDS Bio-Engineered Concrete; Mineral Precipitation; Bio-Culture; Self-Healing; Mechanical Strength.

(c) The Author(s) 2021. This article is distributed under a Creative Commons Attribution-ShareAlike 4.0 International license.

\section{INTRODUCTION}

Concrete's weakness against tension force is always an issue of great concern as it generates cracks, which reduces the performance and durability of composite materials. Although, cracks generation is not a new topic, the remedies have always been significant issues of concern. Furthermore, they act as pathways for moisture, causing the corrosion of the embedded rebar inside the concrete. The generation of both micro and macro cracks also severely damage the properties of the material, which ultimately causes serious long-term problems (Zulfikar et al., 2021). This extremely leads to a decrease in the strength and durability of the concrete, as well as the decay of the structure (Thakur and Singh, 2017). After the construction, remedies to fill up the cracks are often carried out, using a costly and non-eco-friendly method.

Based on the construction industry, a durable and cost-efficient structure is always preferable, as various attempts are often conducted to create high-performance concretes. In this regard, the use of natural resources, e.g., Bio-engineered concrete, is becoming popular, due to having the ability to help eradicate the threat to the environment. Furthermore, Sustainable Development Goals (SDGs) are being globally implemented, as the use of bio-resources is becoming a preferable topic for experts, based on the development of less energy-consuming bioconcrete. These materials mainly focus on the 
pre-construction measures, in order to make durable concretes. Therefore, the process of using bio-culture (bacteria) to heal cracks and improve mechanical properties is widely known as Bio-engineered concrete. This technique incorporates calcite precipitating bacteria within the material in certain concentrations. These bio-cultures precipitate calcium carbonate when in contact with water, and eventually solidifies the cracks (Wiktor and Jonkers, 2015). This biomineralization process is known as Microbiologically Induced Calcite Precipitation (MICP), which involves intracellular hydrolyzation of ammonia and Carbon dioxide. The ammonia present in this process causes an increase in the $\mathrm{pH}$ of the surroundings, which eventually leads to the mixture of the Calcium and carbonate cations that are deposited along the cell surface (Reinhardt and Joss, 2003).

Based on performance evaluation, several studies have been globally conducted on bioengineered concrete, as materials having different bio-culture provided good results than the conventional types (Raina et al., 2018). Furthermore, the properties of concrete were observed to effectively improve when bio-culture is used, based on the eco-friendly features of the material (De Belie, 2016). From Figure 1, the use of bacteria in concrete enriches the microstructural properties, which initiates a new and developed genus of durable material. This study aims to critically analyze the bioengineered concrete, as well as determine the key aspects and applications of its future potentials, through the use of the literature review method.

\section{METHODOLOGY}

This study was conducted by analyzing various published articles, based on the method adopted in using bio-cultures (bacteria) within concrete. The performance of this study was also based on significant results, obtained through key information analyses of the publications. Approximately 39 laboratory-based research articles were reviewed, such as scientific journals, dissertations, and conference proceedings on bio-agent utilization in concrete. Three. potential publications focusing on practical results related to the application of bioengineered materials in structural elements were also analyzed in section 8.2. These research articles were selected based on the titles, keywords and abstracts. In addition, Figure 2 represents the process flow being utilized in conducting this study.

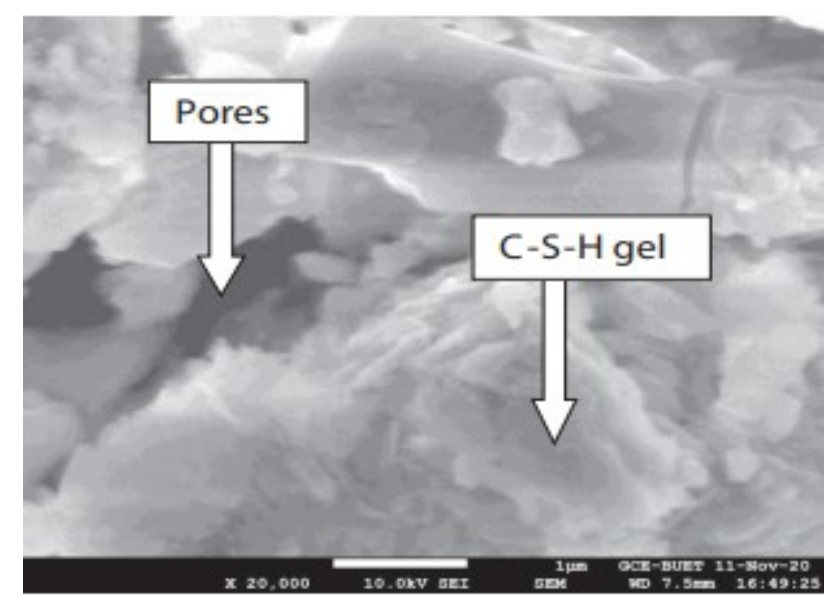

(a)

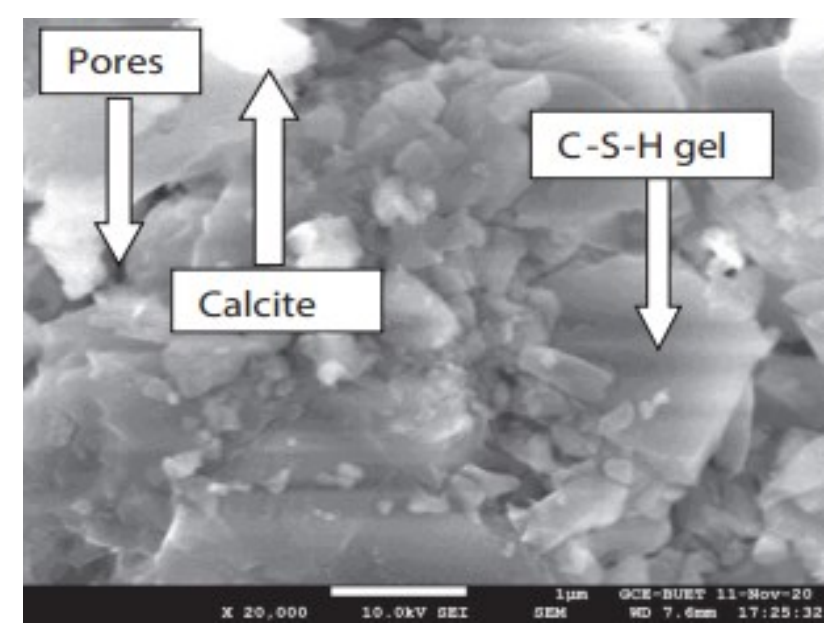

(b)

Figure 1. (a). SEM image showing the less dense microstructure of conventional concrete, (b). dense microstructure of bio-engineered concrete (Priyom et al., 2020). 


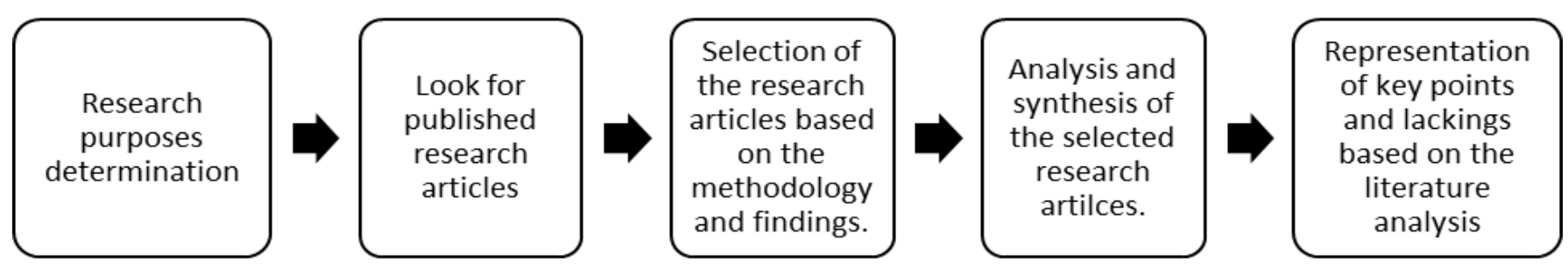

Figure 2. The basic methodology followed for this research article.

\section{HISTORICAL BACKGROUND AND CURRENT PROSPECTS OF BIO-ENGINEERED CONCRETE}

Although the term bio-engineered concrete was new in the field of Structural Engineering, the concept of using bio-cultures (bacteria) was very familiar in increasing microstructural properties. In 1877, Ferdinand Cohn, a German biologist, claimed that the use of bacteria in the field of construction was an effective solution to the development of self-healing material genera. However, the study did not occur during this period, due to a lack of conception.

The use of bio-cultures to efficiently use the biomineralization process was first proposed by Me'tayer-Levrel et al. (1999). This study experimented on the use of bacterial carbonatogenesis, for the protection of architectural monuments. It also stated that the bio-mineralization process was a large field for future research, due to being a useful option to restore broken architectural monuments. In 2006, bio-engineered concrete was invented by Henk Jonkers, a professor at Delft University of Technology. Furthermore, H. Jonkers [7 publications], N. De Belie [7 publications], N.K. Dhami [4 publications], and S. P. Sivkova [5 publications], were prominent experts whose works in bio-agent (bacteria) concretes had generated a new possibility within the construction industry. Major studies based on this material had also been carried out in the last decade (2010-2020). In addition, the first bioengineered concrete sample developed by Henk Jonkers through the encapsulation method, is shown in Figure 3.

Several laboratory and practical experiments had also been carried out on bio-engineered concrete, as various studies indicated that efficient use of bio-cultures developed and enriched self-healing and mechanical properties, respectively. The flow dynamics of publication in this study within the last decade is shown in Figure 4.

Based on Figure 4, a major increment of interest in the study of the bio-engineered concrete occurred between 2014 to 2020, as practical application related to the research became a major focus for future experts.

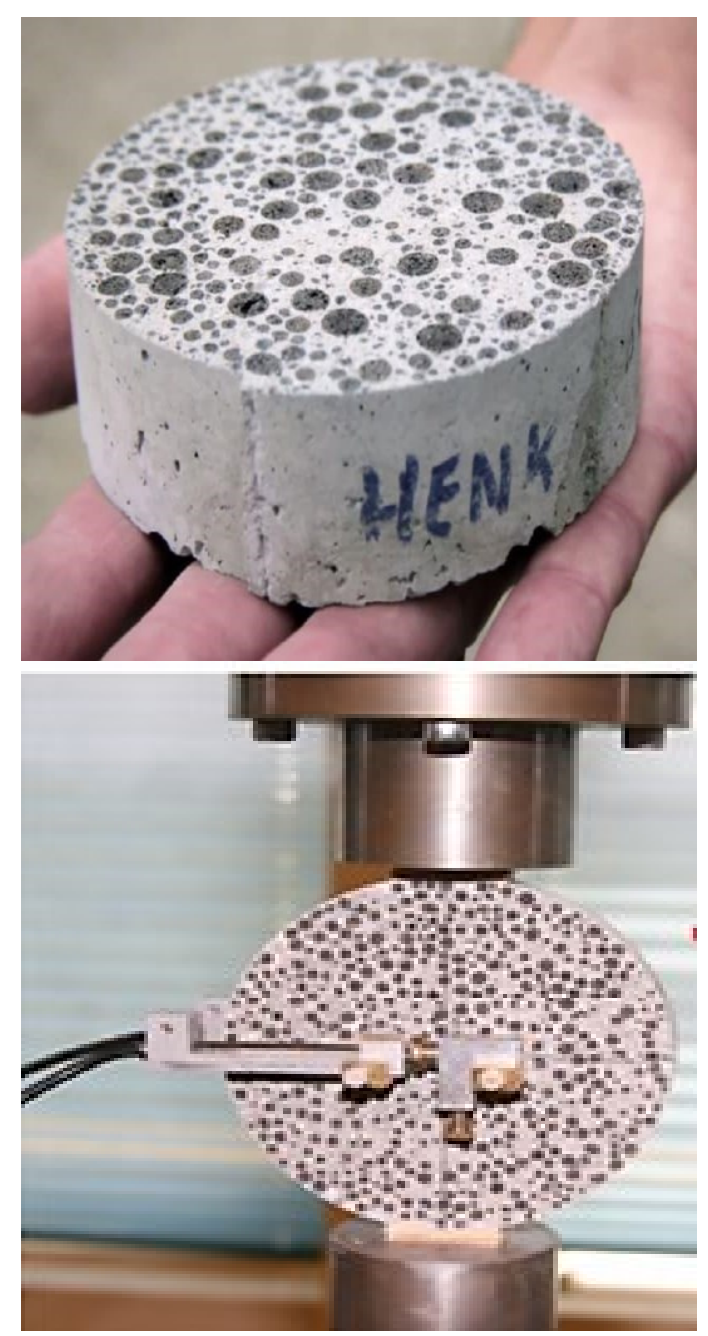

Figure 3. Bio-engineered concrete developed by the encapsulation method (Jonkers, 2011) 


\section{SELECTION OF BIO-AGENT (BACTERIA) IN CONCRETE}

The precipitation of $\mathrm{CaCO}_{3}$ and other inorganic minerals by bacteria was strongly dependent on environmental conditions, which increased due to employing specific metabolic pathways. The designation of the 'Limestone producing bacteria' was always due to a tangible combination of the metabolic pathways, activities, and physicochemical environmental conditions. Therefore, a specific bacterium was 'limestone producing' in one environment, and different in another. The selection of bacteria was also highly dependent on their survivability within the concrete ambience. In addition, the $\mathrm{pH}$ value influenced the limestone precipitation, due to the urease enzyme being only activated for the specific acidic and basic level of Urea hydrolysis. This showed that the bacterial spores activated from the dormant stage had $\mathrm{pH}$ levels of 10-11.5, although they differed from the alkaliphile types and exposure conditions (AboEl-Enein et al., 2013). Carbonate yield also played a vital role during the selection of bioagents, as Table 1 represents the different metabolic pathways of calcium carbonate precipitation (De Belie and Wang, 2015).

\section{METHODS OF APPLICATION OF BIO-AGENT (BACTERIA) IN CONCRETE}

Based on various studies, the following methods are found more feasible,

(1) Direct application method: Bio-cultures containing spores and calcium lactate are added directly into the concrete mix in this method. When cracks occur on the structure, the spores germinate and feed on the calcium lactate, to carry out healing.

(2) Encapsulation method: In this method, treated clay pellets containing bacterial spores and calcium lactate are used in concretes. These pellets are degraded when cracks occur on the structures, as spores are observed to start germinating.

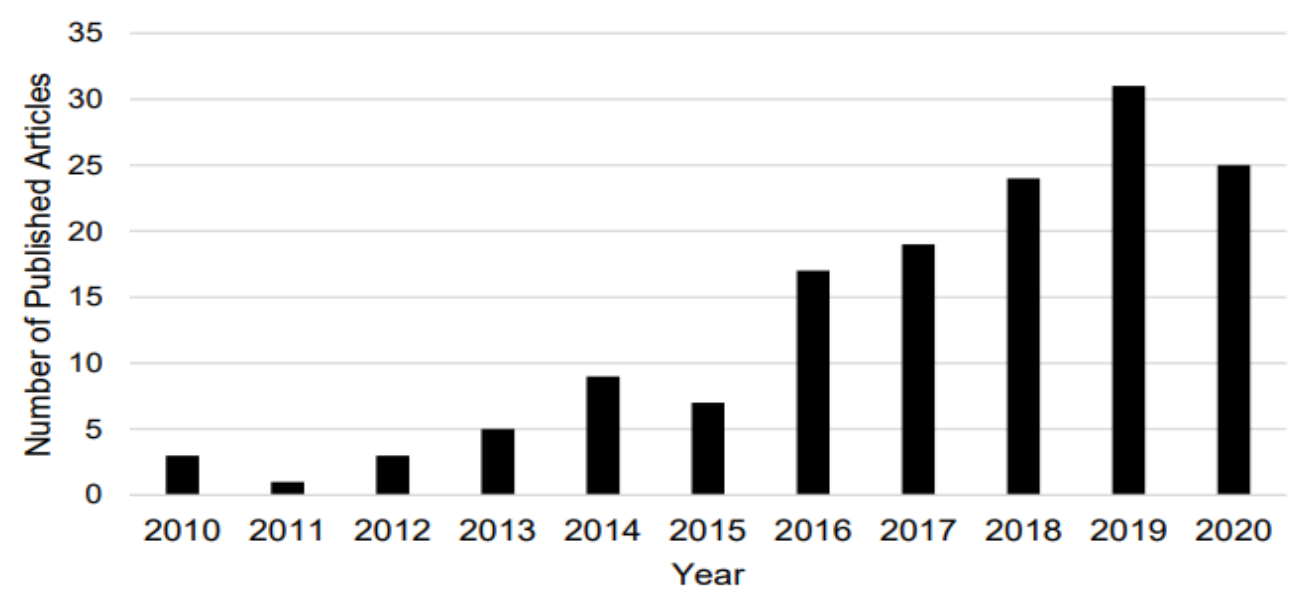

Figure 4. Frequency of published articles on bio-engineered concrete in the last decade.

Table 1. Different metabolic pathways of bacterial calcium carbonate $\left(\mathrm{CaCO}_{3}\right)$ precipitation (Belie et al., 2015)

\begin{tabular}{|c|c|c|c|c|c|}
\hline \multirow{4}{*}{$\begin{array}{l}\text { Autotrophic bacteria } \\
\text { Non-methylotrophic } \\
\text { methanogenesis }\end{array}$} & Heterotrophic bacteria & & & & \\
\hline & Assimilatory pathways & \multicolumn{4}{|c|}{ Dissimilatory pathways } \\
\hline & \multirow{3}{*}{ Urea decomposition } & \multicolumn{4}{|c|}{ Oxidation of organic carbon } \\
\hline & & \multicolumn{2}{|c|}{ Aerobic } & \multicolumn{2}{|c|}{ Anaerobic } \\
\hline \multirow{2}{*}{$\begin{array}{l}\text { Anoxygenic } \\
\text { photosynthesis }\end{array}$} & & Process & $\mathrm{e}^{-}$acceptor & Process & $\mathrm{e}^{-}$acceptor \\
\hline & $\begin{array}{l}\text { Ammonification of } \\
\text { amino- acids }\end{array}$ & Respiration & $\mathrm{O}_{2}$ & $\begin{array}{l}\text { NOx } \\
\text { reduction }\end{array}$ & $\mathrm{NO}_{3}^{-} / \mathrm{NO}_{2}^{-}$ \\
\hline Oxygenic photosynthesis & & $\begin{array}{l}\mathrm{CH}_{4} \\
\text { oxidation }\end{array}$ & $\mathrm{CH}_{4} / \mathrm{O}_{2}$ & $\begin{array}{l}\mathrm{SO}_{4}^{2-} \\
\text { reduction }\end{array}$ & $\mathrm{SO}_{4}{ }^{2-}$ \\
\hline
\end{tabular}


(3) Vascular network method: This is a new method for using the self-healing mechanism, where temporary glass tubes are generally embedded in the concrete during casting. After this, these tubes are removed from the structures and tunnels produced within the structure. In addition, bio-cultures containing spores are then injected through the tunnel, when cracks are formed.

(4) Bio-agent as curing medium: One of the new and most promising techniques to produce bio-concrete is the curation of structural specimens within a medium containing bacterial spores. However, these bio-cultures are not directly applied to the concrete mix.

(5) Spraying bio-culture during curing: When the concrete specimens are cured for a desired limit, the spraying of bacteria-induced liquid is conducted, in order to produce a self-healing nature.

(6) Surface treatment agent: Bio-cultures are used as surface treatment cultures than conventional approaches, to protect the concrete from the ingression of water and other deleterious substances.

(7) Microcapsules enriched encapsulation method: In this method, microcapsule spores are applied into the concrete mix. These capsules are found to participate in self-healing processes, after the generation of cracks.

(8) Bacterial spores enriched powder method: In this method, bacterial spores with calcite ingredients are dry-sprayed within the tank by a peristaltic pump, with the dry powder directly added to the concrete mix

\section{MICROBIAL INDUCED CALCITE PRECIPITATION (MICP)}

The autogenous healing process is a remarkable concrete capacity to naturally repair cracks. This mainly depends on the presence and absence of moisture and tensile stress, respectively. However, it is limited to crack widths below 0.2 $\mathrm{mm}$ (Beltran and Jonkers, 2015). Therefore, the development of a self-healing system filling the cracks of higher widths is becoming a popular topic for present studies. Furthermore, various studies had shown that microbial-induced calcite precipitation (MICP) was a promising technique for developing self-healing genera (Joshi et al., 2017; Silva, 2015). This method mainly focused on the mechanism of calcium carbonate $\left(\mathrm{CaCO}_{3}\right)$ precipitation of bio-cultures, when cracks occurred on the concrete surface. In addition, the bacteria-induced $\mathrm{CaCO}_{3}$ sealed the cracks in the presence of moisture (Wang et al., 2015).

Bio-mineralization in the form of MICP is a process where $\mathrm{CaCO}_{3}$ minerals are formed from a supersaturated solution, in the presence of micro-organisms. Figure 5 represents the basic mechanism of this process. Furthermore, bioagent (bacteria) cells had the abilities to emit carbonate ions $\left(\mathrm{CO}_{3}{ }^{2-}\right)$, which reacted with calcium (Ca)-rich solution and precipitated insoluble $\mathrm{CaCO}_{3}$. Various species of bacteria also produced different phases of calcium carbonate $\left(\mathrm{CaCO}_{3}\right)$. Therefore, calcite is the primary and most thermodynamically stable polymorph of calcium carbonate $\left(\mathrm{CaCO}_{3}\right)$, mostly formed in the MICP reactions (Anbu et al., 2016).

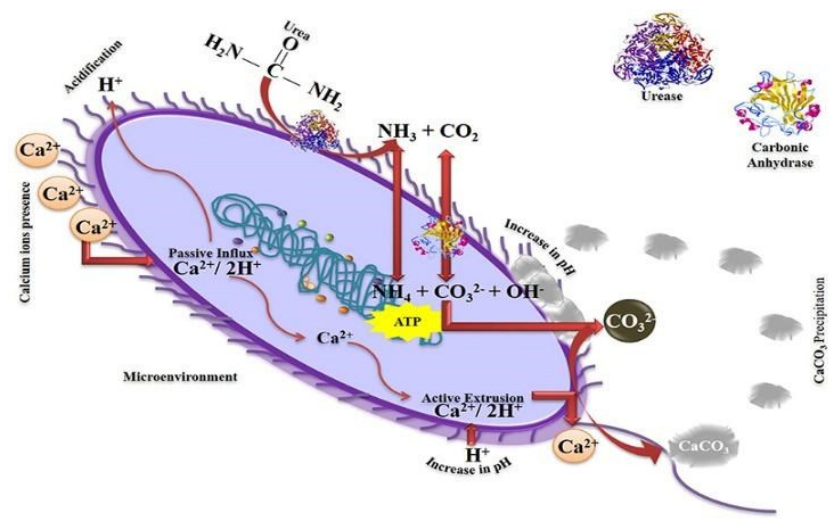

Figure 5. Basic mechanism of calcite precipitation at microbial cell walls (Castro-Alonso et al., 2019)

\section{MECHANISM OF BIO-ENGINEERED CONCRETE}

As previously mentioned, cement mortar has high alkaline and dry ambience, which creates an inhospitable atmosphere for specified lifeforms. However, alkaliphilic bacteria have the viable capabilities to survive in severe and harsh conditions. Different activities such as the $\mathrm{CaCO}_{3}$ 
precipitation, is known as a typical metabolic pathway, leading to the increment of carbonate ion concentration and related saturation.

Based on several studies, the introduction of MICP in concrete was carried out through the enzymatic hydrolysis of urea, which was converted into $\mathrm{NH}_{3}$ and $\mathrm{CO}_{2}$ by bacteria. Therefore, the $\mathrm{pH}$ level increased from neutral to alkaline condition, causing the formation of carbonate. Although the process provided much effective self-healing capability in the concrete, a minor disadvantage was still observed, i.e., non-eco-friendly formation of ammonia. Furthermore, the long-term stability became limited in the alkaline environment within the material, due to the influence of urea. This indicated that the technique accurately performed as an externally applied repair mechanism than a self-healing agent.

Based on the process of MICP, a higher concentration of calcium carbonate was achievable within a short time. Urease also influenced the formation of minerals by four factors, namely concentration of $\mathrm{Ca}^{2+}$, dissolved inorganic carbon ratio, $\mathrm{pH}$ and presence of nucleation sites, and the latter of great importance for continuous and stable calcite crystals formation. However, it was generally carried out by the bacteria lying on the cell surface in Bio-mineralization. This charged with negative groups, as the divalent cations were anchored at a neutral $\mathrm{pH}$ level, which created the ideal nucleation sites for necessary calcite deposition. Meanwhile, magnesium ions made the bond more frequent than the calcium ions, due to having strong ionic selectivity. The bound cations (metal ions) also reacted with anions (carbonates) to form insoluble calcium carbonate. Bacterial cells further affected the type of minerals to be created, due to being nucleation sites. The enzymatic urea hydrolysis procedures are shown in the following chemical reaction (Vijay et al., 2017).

$$
\mathrm{CO}\left(\mathrm{NH}_{2}\right)_{2}+2 \mathrm{H}_{2} \mathrm{O} \stackrel{\text { Microbial urease }}{\longrightarrow} \mathrm{NH}_{2} \mathrm{COOH}+\mathrm{NH}_{3}
$$

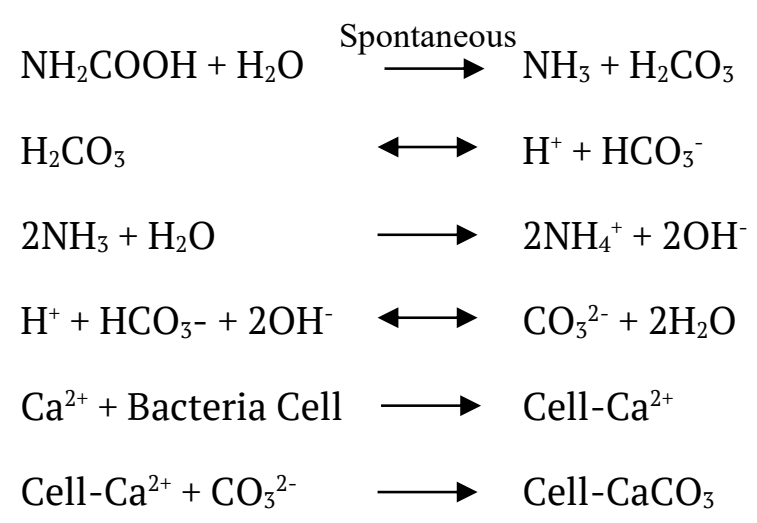

In this urease-mediated process, the reaction of urea $\left(\mathrm{CO}\left(\mathrm{NH}_{2}\right)_{2}\right)$ and water yielded Carbon dioxide $\left(\mathrm{CO}_{2}\right)$, and ammonia $\left(\mathrm{NH}_{3}\right)$. Based on the high $\mathrm{pK}$ value (acid dissociation constant- a quantitative measure of acidic strength in a solution) of the $\mathrm{NH}_{3} / \mathrm{NH}_{4}{ }^{+}$system (about 9.2), the reaction produced a $\mathrm{pH}$ increase and concomitantly shifted in the carbonate equilibrium $\left(\mathrm{CO}_{2}\right.$ to $\mathrm{HCO}_{3}^{-}$and $\left.\mathrm{CO}_{3}^{-2}\right)$. This caused the precipitation of $\mathrm{CaCO}_{3}$, when a sufficient amount of calcium ions $\left(\mathrm{Ca}^{2+}\right)$ was present.

Based on Figure 6, the generation of calcium carbonate $\left(\mathrm{CaCO}_{3}\right)$ in the mortar sample surface (inner and outer) was observed, showed due to the addition of bio-cultures. The generation of this compound did not only act as a crack healer, it also developed the mechanical properties of concretes. The use of these carbonate-producing bio-cultures filled the pores of the cement-sand matrix (Stooks-Fischer et al., 1999), causing the development of concretes with low permeability and higher strength.

\section{LITERATURE ANALYSIS}

\subsection{Review of laboratory-based research study focusing on strength properties, microstructure and self-healing capability}

This aspect focused on the laboratory-based articles that mainly investigated the healing capacity and ability of bio-genus as a strength increaser. Table 2 shows the analysis of the selected studies. 

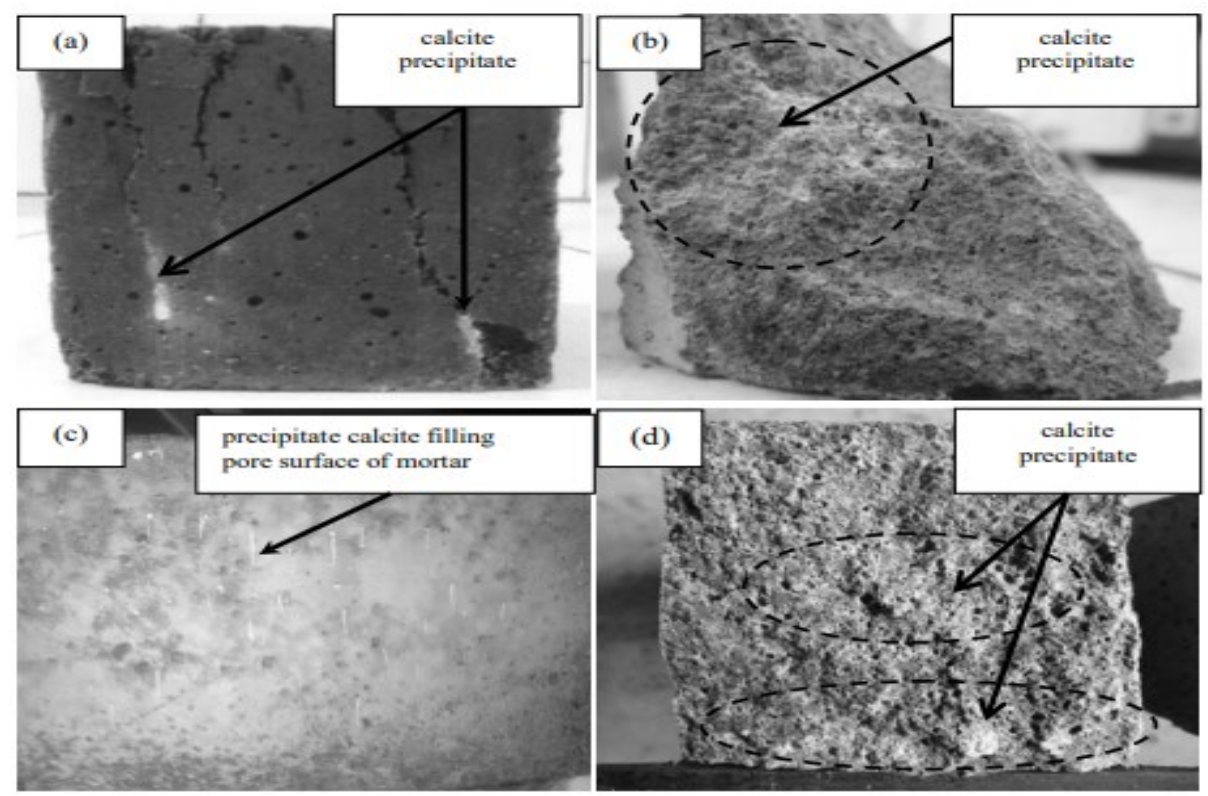

Figure 6. Precipitation of calcium carbonate in the outer and inner surface of mortar samples having bacterial spores in the mix (Nugroho et al., 2015)

Table 2. Literature analysis of Bio-agent enriched laboratory-based research

\begin{tabular}{|c|c|c|c|}
\hline Bio-agent used & Methodology & Major outcomes & References \\
\hline $\begin{array}{l}\text { Bacillus } \\
\text { pseudofirmus } \\
\text { and } \\
\text { Diaphorobacter } \\
\text { nitroreducens }\end{array}$ & $\begin{array}{ll}\text { a. } & \text { Encapsulation } \\
\text { method } \\
\text { b. } & \text { Bacterial strains } \\
& \text { were added as } \\
0,0.5,1.5, \text { and } \\
\text { 3.0\% of cement } \\
\text { weight }\end{array}$ & $\begin{array}{l}\text { a. Lower concentration of alginate beads within the capsule had } \\
\text { very little significance on strength properties. } \\
\text { b. Specimens with higher calcium alginate concentrations } \\
\text { provided greater stiffness recovery. } \\
\text { c. Samples having calcium alginate had superior self-healing } \\
\text { ability over controlled concrete. } \\
\text { d. Lower concentrations of alginate beads did not yield } \\
\text { significant differences in compressive strength (at } 0.5 \% \text { by wt. } \\
\text { of cement) and elasticity modulus (at } 0.5 \% \text { and } 1.5 \% \text { by wt. of } \\
\text { cement), compared to the control specimens. }\end{array}$ & $\begin{array}{l}\text { Hassan et al., } \\
(2019)\end{array}$ \\
\hline
\end{tabular}

Bacillus

sphaericus a. Direct application

b. Bacterial spores with and without immobilized silica gel were directly added to the cracks

Sporosarcina
pasteurii a. Culture protected with silica gel showed better performance.

b. Crack sealing by bacterial approach reduced the water permeability of concrete.

c. Bacteria, immobilized with silica gel accurately sealed the cracks than others.
Tittelboom et al., (2010) a. Ceramsite particles were used as a career of bio-agent.

b. Porous ceramsite particles with nutrients and bacterial spores were applied to the concrete mix a. The viability of the bacterial spores within the concrete Ceramsite particles played an important role.

Xu et al., (2018)

b. Bacterial concrete showed a $20 \%$ increment in compressive strength than the control specimens.

c. Bacteria concrete had $30 \%$ less water absorption ratio than the control specimens.

d. Based on the mechanism of the self-healing process, the maximum width filled with precipitated calcite was $0.3 \mathrm{~mm}$.

e. Nutrients were frequently and easily accessed to the cells, when the bacteria and nutrients were incorporated within the Ceramsite particles. 
Table 2. Literature analysis of Bio-agent enriched laboratory-based research (Cont.)

\begin{tabular}{|c|c|c|c|}
\hline Bio-agent used & Methodology & Major outcomes & References \\
\hline Bacillus cereus & $\begin{array}{ll}\text { a. } & \text { Direct } \\
\text { application } \\
\text { b. } & 35 \% \text { of cement } \\
& \text { replaced by fly } \\
& \text { ash was also } \\
& \text { added }\end{array}$ & $\begin{array}{l}\text { a. At } 28 \text { days, 9.93\% compressive strength was increased for the } \\
\text { bacterial concrete, compared to the conventional specimens. } \\
\text { b. Water absorption capacity for bacterial concrete was } 1.98 \% \text {, } \\
\text { which was less than half of the conventional type. }\end{array}$ & $\begin{array}{l}\text { Selvan and } \\
\text { Dharani, } \\
(2016)\end{array}$ \\
\hline $\begin{array}{l}\text { Paenibacillus } \\
\text { muscilaginosus }\end{array}$ & 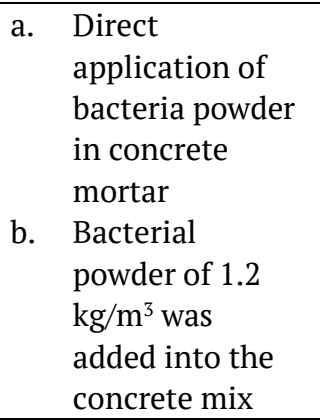 & $\begin{array}{l}\text { After healing, } \\
\text { a. Bio-concrete: } 0 \text { to } 135 \mu \mathrm{A} \text { (corrosion current) and }-150 \text { to }-550 \\
\mathrm{mV} \text { (corrosion potential), } \\
\text { Normal concrete: } 50 \text { to } 150 \mu \mathrm{A} \text { (corrosion current) and }-250 \text { to } \\
-600 \mathrm{mV} \text { (corrosion potential) } \\
\text { b. Bacterial concrete by healing cracks decreased the process of } \\
\text { reinforced corrosion. } \\
\text { c. The bio-concrete chloride contents at } 5 \text { and } 10 \mathrm{~mm} \text { depth } \\
\text { were } 0.02 \% \text { lower than the conventional type. }\end{array}$ & $\begin{array}{l}\text { Ling and } \\
\text { Qian, (2017) }\end{array}$ \\
\hline $\begin{array}{l}\text { S. pasteurii } \\
\text { and } \\
\text { Bacillus subtilis }\end{array}$ & 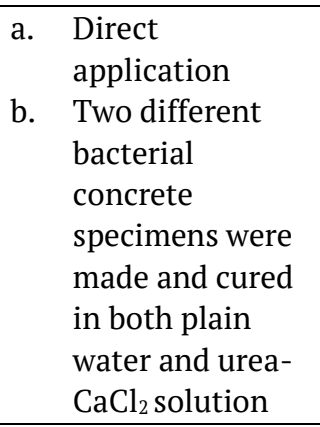 & $\begin{array}{l}\text { a. Bacterial concrete cured in urea-CaCl} 2 \text { was found to prolong } \\
\text { cement hydration. } \\
\text { b. Specimens cured in urea- } \mathrm{CaCl}_{2} \text { showed less mass increment } \\
\text { than those in water. } \\
\text { c. Increment of bulk density and reduction of voids were found } \\
\text { in bacterial concrete. } \\
\text { d. Compressive strength of bacterial concrete approximately } \\
\text { increased by 20\%, which was more than the conventional } \\
\text { type, as reduction of chloride penetration was also observed. } \\
\text { e. S. pasteurii concrete showed better strength performance. }\end{array}$ & $\begin{array}{l}\text { Nosouhian et } \\
\text { al., (2015) }\end{array}$ \\
\hline $\begin{array}{l}\text { Bacillus } \\
\text { pseudofirmus }\end{array}$ & $\begin{array}{ll}\text { a. } & \begin{array}{l}\text { Encapsulation } \\
\text { method }\end{array} \\
\text { b) Coated perlite } & \begin{array}{l}\text { Coted nutrient } \\
\text { with nu } \\
\text { was applied to } \\
\text { the mix }\end{array} \\
\end{array}$ & $\begin{array}{l}\text { a. A reinforced concrete wall was made with bacterial concrete } \\
\text { for further investigations after trial. } \\
\text { b. Healing of cracks was initiated in bio-concrete. } \\
\text { c. Encapsulation method did not modify the basic properties of } \\
\text { concrete. }\end{array}$ & $\begin{array}{l}\text { Paine et al., } \\
(2016)\end{array}$ \\
\hline $\begin{array}{l}\text { Bacillus flexus, } \\
\text { Bacillus pasteurii } \\
\text { and } \\
\text { Bacillus } \\
\text { sphaericus }\end{array}$ & $\begin{array}{l}\text { Microbial culture } \\
\text { used as the medium } \\
\text { of curing specimens }\end{array}$ & $\begin{array}{l}\text { a. A maximum of } 18 \% \text { compressive strength was increased by } \\
\text { using bacterial approach, as Bacillus flexus containing } \\
\text { specimens showed great result. } \\
\text { b. B. pasteurii and B. sphaericus showed marginally less strength } \\
\text { than } B \text {. flexus. } \\
\text { c. All the bacteria were urease positive. } \\
\text { d. XRD analysis showed the phenomenon of bio-mineralization. }\end{array}$ & $\begin{array}{l}\text { Jagadeesha et } \\
\text { al., (2013) }\end{array}$ \\
\hline Bacillus subtilis & $\begin{array}{l}\text { Direct application of } \\
\text { four different } \mathrm{OD}_{600} \\
\text { spores }\end{array}$ & $\begin{array}{l}\text { a. UPV test indicated that bacterial concrete possessed higher } \\
\text { density and compactness than the conventional type. } \\
\text { b. Specimens having } \mathrm{OD}_{600}=0.637 \text { showed better performance. }\end{array}$ & $\begin{array}{l}\text { Priyom et al., } \\
(2018)\end{array}$ \\
\hline $\begin{array}{l}\text { Sporosarcina } \\
\text { pasteurii, } \\
\text { Bacillus cohnii, } \\
\text { Bacillus } \\
\text { halodurans } \\
\text { and } \\
\text { Bacillus } \\
\text { pseudofirmus }\end{array}$ & $\begin{array}{ll}\text { a. } & \text { Direct } \\
\text { application } \\
\text { b. } & \text { Re-suspension } \\
\text { bacterial } \\
\text { culture was } \\
\text { added as a } \\
\text { medium of the } \\
\text { water required } \\
\text { for the concrete } \\
\text { mix }\end{array}$ & $\begin{array}{l}\text { a. Except for S. pasteurii, three strains showed abundant } \\
\text { production of spores in the mineral medium. } \\
\text { b. B. psedufirmus had the highest viability rate of } 7.0 \% \text {. } \\
\text { c. From the ESEM analysis, high amount of calcite-like crystals } \\
\text { were formed in the bacterial concrete. } \\
\text { d. Incorporation of high bacteria amount }\left(10^{9} / \mathrm{cm}^{3}\right) \text { did not affect } \\
\text { the strength of concrete. } \\
\text { e. Bacterial concrete had the ability of self-healing. }\end{array}$ & $\begin{array}{l}\text { Jonkers \& } \\
\text { Schlangen, } \\
(2007)\end{array}$ \\
\hline
\end{tabular}


Table 2. Literature analysis of Bio-agent enriched laboratory-based research (Cont.)

\begin{tabular}{|c|c|c|c|}
\hline Bio-agent used & Methodology & Major outcomes & References \\
\hline $\begin{array}{l}\text { Bacillus } \\
\text { sphaericus } \\
\text { andBacillus } \\
\text { pasteurii }\end{array}$ & $\begin{array}{ll}\text { a. } & \begin{array}{l}\text { Direct } \\
\text { application }\end{array} \\
\text { b. } & \text { Bacterial } \\
& \text { culture was } \\
& \text { added as 10, } 20 \\
& \text { and 30\% of } \\
& \text { cement weight } \\
\text { b. } & \text { Fly ash was } \\
& \text { added as 10, } 20 \\
\text { and 30\% } \\
\text { replacement of } \\
\text { cement }\end{array}$ & $\begin{array}{l}\text { a. Concrete specimens containing fly ash and Bacillus sphaericus } \\
\text { showed better performance. } \\
\text { b. Concrete specimens containing fly ash and Bacillus pasteurii } \\
\text { showed marginally less performance than those with } B \text {. } \\
\text { sphaericus. } \\
\text { c. Concrete specimens containing bio-cultures showed better } \\
\text { performance than conventional types. } \\
\text { d. A maximum of compressive, split tensile, and flexural } \\
\text { strengths at } 10.8,29.87 \text {, and 5.1\%, was increased by using } \\
\text { Bacillus sphaericus. }\end{array}$ & $\begin{array}{l}\text { Jagannathan } \\
\text { et al., (2018) }\end{array}$ \\
\hline E. coli & $\begin{array}{l}\text { a. Continuous } \\
\text { growth setup } \\
\text { was designed to } \\
\text { grow bio-film } \\
\text { on mortar cubes } \\
\text { b. E. coli culture } \\
\text { was injected } \\
\text { into the } \\
\text { medium }\end{array}$ & $\begin{array}{l}\text { a. The results from the ATP measurement and member filtration } \\
\text { showed intensive continuous biomass concentration. } \\
\text { b. SEM micrographs showed that the biofilm on the mortar } \\
\text { surface was fairly distributed after } 8 \text { days. } \\
\text { c. The result from the elemental mapping (EDS analysis) showed } \\
\text { that there was an increase of } 2.4 \% \text { atomic fraction of the } \\
\text { constituent Phosphorous, which was mainly liable for the } \\
\text { formation of bio-film. } \\
\text { d. Formation of biofilm on mortar surface was eco-friendly, } \\
\text { cost-effective, and self-plenishing. }\end{array}$ & $\begin{array}{l}\text { Soleimani et } \\
\text { al., (2013) }\end{array}$ \\
\hline $\begin{array}{l}\text { Bacillus } \\
\text { megaterium }\end{array}$ & $\begin{array}{ll}\text { a. } & \text { Direct } \\
& \text { application } \\
\text { b. } & \text { A 2-phased } \\
& \text { diagram was } \\
\text { adopted for bio- } & \text { agent selection. } \\
\text { c. } & \text { After XRD } \\
& \text { analysis, the } \\
& \text { bacteria } \\
\text { identification } \\
\text { step was } \\
\text { initiated }\end{array}$ & $\begin{array}{l}\text { a. Strength development rate for higher-grade concrete (50 } \\
\mathrm{MPa} \text { ) was } 24 \% \text { (maximum), which was greater than the lower } \\
\text { level structure, due to increased intensity of calcite } \\
\text { precipitation. } \\
\text { b. Bacterial concentration of } 30 \times 10^{5} \mathrm{cfu} / \mathrm{ml} \text { was optimal, due to } \\
\text { obtaining positive characteristics from the concrete samples. } \\
\text { c. For bacterial concentration of } 30 \times 10^{5} \mathrm{cfu} / \mathrm{ml} \text {, concrete samples } \\
\text { had more calcite precipitation rate, due to its maximum } \\
\text { compressive \& flexural strength. } \\
\text { d. In the construction industry, } B \text {. megaterium was part of green } \\
\text { building material. }\end{array}$ & $\begin{array}{l}\text { Andalib et al., } \\
(2016)\end{array}$ \\
\hline Bacillus subtilis & $\begin{array}{l}\text { a. Direct } \\
\text { application } \\
\text { b. Depending on } \\
\text { the cell } \\
\text { concentration, } \\
8 \text { different } \\
\text { bacterial agents } \\
\text { were added to } \\
\text { the concrete } \\
\text { mix }\end{array}$ & $\begin{array}{l}\text { a. Bacterial specimens showed better strength performance than } \\
\text { conventional concrete. } \\
\text { b. The concentrations of } 6.39 \times 10^{8} \text { cells } / \mathrm{ml} \text { were optimal for } \\
\text { strength increment. } \\
\text { c. } 60 \% \text { bacterial water provided better result. } \\
\text { d. Bacterial concrete strength increment for } 40 \mathrm{MPa} \text { was } 2-10 \% \\
\text { higher than the } 20 \mathrm{MPa} \text { specimens. } \\
\text { e. The concentration of } 6.39 \times 10^{8} \text { cells } / \mathrm{ml} \text { was highly optimal } \\
\text { for strength increment. }\end{array}$ & $\begin{array}{l}\text { Islam et al., } \\
(2018)\end{array}$ \\
\hline $\begin{array}{l}\text { Bacillus } \\
\text { sphaericus }\end{array}$ & $\begin{array}{l}\text { a. Surface } \\
\text { treatment agent } \\
\text { b. } \text { Specimens were } \\
\text { immersed in } \\
\text { the bacterial } \\
\text { culture of } 0.3 \\
\text { and } 0.6 \mathrm{~L}, \\
\text { before } \\
\text { submersion in } \\
\text { the nutrient } \\
\text { solution. }\end{array}$ & $\begin{array}{l}\text { a. Concrete specimens were immersed in Bacillus sphaericus } \\
\text { culture for } 24 \mathrm{~h} \text {, before being submerged in } 0.3 \text { and } 0.6 \mathrm{~L} \text { of } \\
\text { nutrient solutions. } \\
\text { b. SEM and XRD analysis indicated the presence of a newly } \\
\text { formed calcite layer on the surfaces of bacterial specimens. } \\
\text { c. Decrements in capillary suction and gas permeability were } \\
\text { recorded for bacterial concrete. } \\
\text { d. } \mathrm{CaCO}_{3} \text { crystal morphography was observed. } \\
\text { e. Bacterial specimens performed better in all aspects than the } \\
\text { controlled concrete. }\end{array}$ & $\begin{array}{l}\text { De Muynck } \\
\text { (2008) }\end{array}$ \\
\hline
\end{tabular}


Table 2. Literature analysis of Bio-agent enriched laboratory-based research (Cont.)

\begin{tabular}{|c|c|c|c|}
\hline Bio-agent used & Methodology & Major outcomes & References \\
\hline & $\begin{array}{ll}\text { c. } & \text { Centrifuged } \\
\text { ureolytic sludge } \\
\text { were added }\end{array}$ & & \\
\hline $\begin{array}{l}\text { Bacillus } \\
\text { megaterium }\end{array}$ & 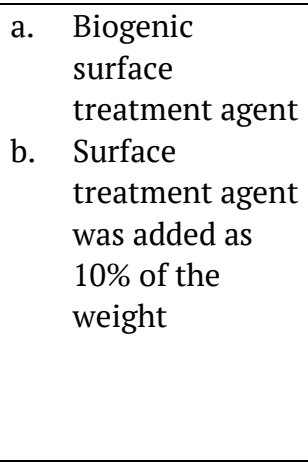 & $\begin{array}{l}\text { a. During } 28 \text { days of curing, the specimens' surfaces were } \\
\text { regularly treated with } 30 \mathrm{ml} \text { solution and precursors. } \\
\text { b. Bacterial specimens showed } 40 \% \text { less water absorption } \\
\text { capacity than the conventional concrete. } \\
\text { c. Bacterial concrete showed a } 31 \% \text { decrement in porosity than } \\
\text { the conventional specimen. } \\
\text { d. Bacterial specimen showed a } 22 \% \text { increment in compressive } \\
\text { strength, which was further improved to } 18 \% \text { more than the } \\
\text { conventional concrete during freeze thaw test. } \\
\text { e. SEM and XRD analysis established the presence of calcite } \\
\text { crystals on the bacterial concrete. }\end{array}$ & $\begin{array}{l}\text { Dhami et al., } \\
\text { (2013) }\end{array}$ \\
\hline $\begin{array}{l}\text { Bacillus } \\
\text { sphaericus }\end{array}$ & 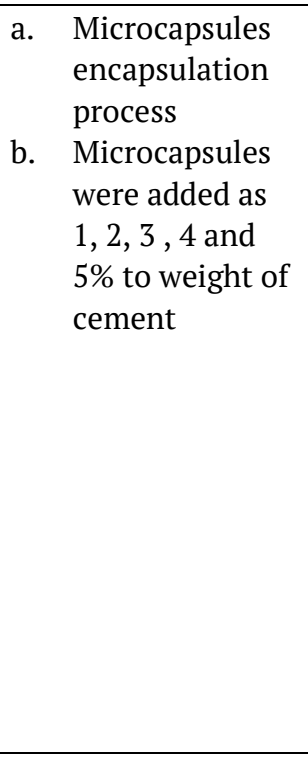 & $\begin{array}{l}\text { a. Microcapsule dosage higher than } 3 \% \text { showed a significant (At } \\
\text { a confidence level of } 0.05 \text { ) and negative effect on tensile } \\
\text { strength. } \\
\text { b. Increasing addition of microcapsules at } 1-5 \% \text { showed a } \\
\text { decrement in compressive strength by } 15-34 \% \text {, based on the } \\
28 \text { days curing age. } \\
\text { c. For } 90 \text { days of curing, the decrement in compressive strength } \\
\text { was } 22-47 \% \text {. } \\
\text { d. Healing ratio in the bio-specimens and controlled concretes } \\
\text { were } 48-80 \% \text { and } 18-50 \% \text {. } \\
\text { e. Maximum crack width healed by bacterial specimens was } \\
970 \mu \text { m, which was } 4 \text { times lower in non-bacterial concretes at } \\
250 \mu \text { m. } \\
\text { f. Bacterial specimens showed that water permeability was } 10 \\
\text { times lower than the control concretes. } \\
\text { g. At } 95 \% \text { RH, no self-healing was observed for all specimens, } \\
\text { which strongly indicated the importance of the moisture } \\
\text { presence. }\end{array}$ & $\begin{array}{l}\text { Wang et al., } \\
(2014)\end{array}$ \\
\hline $\begin{array}{l}\text { Bacillus } \\
\text { sphaericus }\end{array}$ & $\begin{array}{l}\text { a. Direct } \\
\text { application } \\
\text { b. } 10 \text { and } 20 \mathrm{ml} \\
\text { bio-cultures } \\
\text { were directly } \\
\text { added to the } \\
\text { concrete mix }\end{array}$ & $\begin{array}{l}\text { a. For } 10 \text { and } 20 \mathrm{ml} \text { addition, the compressive strength of } \\
\text { bacterial specimens were } 30.84 \text { and } 31.11 \% \text {, respectively, } \\
\text { which were higher than the conventional concrete. } \\
\text { b. Increment in tensile strength was approximately } 1.80 \text { and } \\
5.82 \% \text { for } 10 \text { and } 20 \mathrm{ml} \text { culture addition. } \\
\text { c. Higher amount of culture addition showed better } \\
\text { performance. }\end{array}$ & $\begin{array}{l}\text { Gandhimathi } \\
\text { et al., (2015) }\end{array}$ \\
\hline $\begin{array}{l}\text { Sporosarcina } \\
\text { pasteurii }\end{array}$ & $\begin{array}{l}\text { a. Direct } \\
\text { application } \\
\text { b. Normal and } \\
\text { light weight } \\
\text { coarse } \\
\text { aggregates were } \\
\text { added into the } \\
\text { concrete mix. }\end{array}$ & $\begin{array}{l}\text { a. The coarse aggregates were left to soak in a bacterial inoculum } \\
\text { with precursors for } 6 \text { days, and applied to the concrete mix. } \\
\text { b. An average of } 10 \% \text { reduction in water absorption was } \\
\text { observed for bacterial concrete. } \\
\text { c. Bacterial concrete showed an average of } 20 \% \text { increment in } \\
\text { compressive strength. } \\
\text { d. The RCPT test showed a } 20 \% \text { reduction in chloride } \\
\text { penetration than the controlled concrete. } \\
\text { e. The SEM analysis showed denser and lower porosity of LWCA } \\
\text { bacterial specimens. }\end{array}$ & $\begin{array}{l}\text { Balam et al., } \\
\text { (2017) }\end{array}$ \\
\hline Bacillus pumilus & $\begin{array}{ll}\text { a. } & \begin{array}{l}\text { Direct } \\
\text { application }\end{array} \\
\text { b. } & \text { As a curing } \\
\text { agent having } & \\
& 1.5 \times 10^{8}, \\
\text { b. } & 12 \times 10^{8} \text { and } \\
& 24 \times 10^{8} \text { cells } / \mathrm{ml}\end{array}$ & $\begin{array}{l}\text { a. In the case of direct application, } 1.5 \times 10^{8} \text { cells } / \mathrm{ml} \text { showed } \\
\text { better performance in compressive strength test. Also, a } 6.3 \% \\
\text { increment in compressive strength was observed than the } \\
\text { conventional specimen at } 28 \text { days. } \\
\text { b. For bacterial specimens } 24 \times 10^{8} \text { cells } / \mathrm{ml} \text { concentration } \\
\text { showed better performance in compressive strength test. }\end{array}$ & $\begin{array}{l}\text { Oriola et al., } \\
(2018)\end{array}$ \\
\hline
\end{tabular}


Table 2. Literature analysis of Bio-agent enriched laboratory-based research (Cont.)

\begin{tabular}{|c|c|c|c|}
\hline Bio-agent used & Methodology & Major outcomes & References \\
\hline & & $\begin{array}{l}\text { c. At } 28 \text { days, the weight losses for bacterial specimens were } \\
11.8,17.8 \text {, and } 14.2 \% \text { for } 1.5 \times 10^{8}, 12 \times 10^{8} \text {, and } 24 \mathrm{X} 10^{8} \text { cells } / \mathrm{ml} \text {, } \\
\text { respectively. However, it was } 16.5 \% \text { for conventional } \\
\text { concrete. } \\
\text { d. At } 90 \text { days, the weight losses for bacterial specimens were } \\
15.5,15.7 \text {, and } 15 \% \text { for } 1.5 \times 10^{8}, 12 \times 10^{8} \text {, and } 24 \mathrm{X} 10^{8} \text { cells } / \mathrm{ml} \text {, } \\
\text { respectively. However, it was } 16.5 \% \text { for conventional } \\
\text { concrete. } \\
\text { e. Specimens containing } 1.5 \times 10^{8} \text { and } 24 \times 10^{8} \text { cells } / \mathrm{ml} \text { showed } \\
\text { better performances in the compressive strength increment } \\
\text { and durability test within all aspects. }\end{array}$ & \\
\hline Bacillus sp. CT-5 & $\begin{array}{ll}\text { a. } & \text { Direct } \\
\text { application } \\
\text { b. } & \text { Bio-culture to } \\
\text { w/c ratio was } \\
0.47\end{array}$ & $\begin{array}{l}\text { a. The result of compressive strength test showed a } 30 \% \\
\text { increment for bacterial specimens than that of the controlled } \\
\text { concrete. } \\
\text { b. Bacterial concrete absorbed } 6 \% \text { less water than the controlled } \\
\text { cubes. }\end{array}$ & $\begin{array}{l}\text { Achal et al., } \\
(2010)\end{array}$ \\
\hline $\begin{array}{l}\text { Rhodobacter } \\
\text { capsulatus }\end{array}$ & $\begin{array}{ll}\text { a. } & \begin{array}{l}\text { Direct } \\
\text { application }\end{array} \\
\text { b. } & \begin{array}{l}\text { Bacterial spores } \\
\text { of } 4.6 \mathrm{X} 10^{6} \\
\text { cell/ml were }\end{array} \\
\text { added to the } \\
\text { mix } \\
\text { c. Super } \\
\text { absorbent } \\
\text { polymer were } \\
\text { used at 30\% } \\
\text { volume of fine } \\
\text { aggregate } \\
\text { replacement in } \\
\text { the concrete } \\
\text { mix }\end{array}$ & $\begin{array}{l}\text { a. The bacterial strain as an isolated and super absorbent } \\
\text { polymer, was employed for immobilization, and was also } 30 \% \\
\text { volume for replacements of fine aggregates in coating } \\
\text { mortars. } \\
\text { b. At } 28 \text { days, compressive strength of the bacterial and } \\
\text { conventional concretes were } 40.7 \text { and } 38.9 \mathrm{MPa} \text {, respectively. } \\
\text { c. Approximately } 38 \% \text { increment in compressive strength was } \\
\text { observed in the bacterial concrete. } \\
\text { d. The compressive strength coefficient after exposure of the } \\
\text { samples in a } 5 \% \mathrm{H}_{2} \mathrm{SO}_{4} \text { solution, was } 1.02 \text { and } 0.97 \text { for bacterial } \\
\text { and conventional concretes, respectively. } \\
\text { e. Due to } \mathrm{H}_{2} \mathrm{SO}_{4} \text { solution reaction, gypsum production was } 17 \% \\
\text { lower for bacterial concrete than the conventional specimens. }\end{array}$ & $\begin{array}{l}\text { Yoon et al., } \\
(2019)\end{array}$ \\
\hline $\begin{array}{l}\text { Bacillus } \\
\text { pseudofirmus }\end{array}$ & $\begin{array}{l}\text { Encapsulation } \\
\text { process }\left(1.4 \mathrm{X} 10^{9},\right. \\
3.2 \mathrm{X} 10^{9}, 5.5 \times 10^{9} \\
8.6 \mathrm{X} 10^{9} \text { and } 13 \mathrm{X} 10^{9} \\
\text { cells } / \mathrm{ml})\end{array}$ & $\begin{array}{l}\text { a. Crack closure was observed for specimens containing } 5.5 \times 10^{9} \\
\text { and } 8.6 \times 10^{9} \text { cells } / \mathrm{ml} \text {, after } 165 \text { days. } \\
\text { b. Sufficient healing compounds were not enough, as minimal } \\
\text { bacterial spores were also required. }\end{array}$ & $\begin{array}{l}\text { Alazhari et } \\
\text { al., (2018) }\end{array}$ \\
\hline Bacillus subtilis & 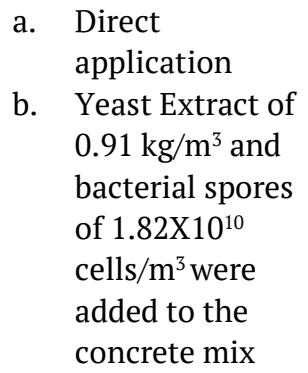 & $\begin{array}{l}\text { a. The permeability and porosity for all tested concrete } \\
\text { decreased with the increase in curing period. } \\
\text { b. Bacterial concrete with } 400 \mu \mathrm{m} \text { cracks were completely closed } \\
\text { after } 44 \text { days. } \\
\text { c. Bacterial concrete culture manifested better resistance } \\
\text { against capillary suction. } \\
\text { d. Bacterial specimens containing yeast extract and peptone } \\
\text { e. A substantial decrease in gas permeability was also observed }\end{array}$ & $\begin{array}{l}\text { Nguyen et al., } \\
(2019)\end{array}$ \\
\hline
\end{tabular}

\begin{tabular}{|c|c|c|c|c|c|}
\hline $\begin{array}{l}\text { B. subtilis, Brevi } \\
\text { B. sp., } \\
P . \text { dendritiformis, } \\
\text { B. } \\
\text { methylotrophicus, } \\
\text { B. licheniformis } \\
\text { and S. } \\
\text { maltophilia }\end{array}$ & a. & $\begin{array}{l}\text { Direct } \\
\text { application } \\
\text { Six different } \\
\text { alkaliphilic } \\
\text { bacteria of } 10^{4} \\
\text { and } 10^{6} \text { cells } / \mathrm{ml} \\
\text { concentrations } \\
\text { were added to }\end{array}$ & a. & $\begin{array}{l}\text { Specimens containing } 10^{4} \text { cells } / \mathrm{ml} \text { showed better } \\
\text { performances. } \\
\text { Compared to conventional concrete strength, the increment } \\
\text { for bacteria specimens are, } \\
\text { B. subtilis - } 28.61 \% \text {, } \\
\text { Brevibacillus } s p-22.1 \% \text {, } \\
\text { P. dendritiformis }-19.9 \% \text {, } \\
\text { B. methylotrophicus }-16 \% \text {, } \\
\text { B. licheniformis }-12.7 \% \text {, }\end{array}$ & $\begin{array}{l}\text { Sreenivasulu } \\
\text { et al., (2018) }\end{array}$ \\
\hline
\end{tabular}


Table 2. Literature analysis of Bio-agent enriched laboratory-based research (Cont.)

\begin{tabular}{|c|c|c|c|}
\hline Bio-agent used & Methodology & Major outcomes & References \\
\hline & $\begin{array}{l}\text { the concrete } \\
\text { mix }\end{array}$ & $\begin{array}{l}\text { S. maltophilia }-9.6 \% \text {. } \\
\text { c. SEM analysis showed calcite precipitation for all type of bio- } \\
\text { groups. }\end{array}$ & \\
\hline $\begin{array}{l}\text { Bacillus } \\
\text { coagulans }\end{array}$ & $\begin{array}{l}\text { a. Direct } \\
\text { Application } \\
\text { b. Bacterial spores } \\
\text { pf } 1.5 \times 10^{8}, \\
12 \times 10^{8} \text { and } \\
24 \times 10^{8} \text { cell } / \mathrm{ml} \\
\text { concentrations } \\
\text { were added to } \\
\text { the concrete } \\
\text { mix }\end{array}$ & $\begin{array}{l}\text { a. B. coagulans concrete showed the property of early strength } \\
\text { than the conventional specimens. A maximum of } 6.25 \% \\
\text { increment in compressive strength was observed for } 24 \times 10^{8} \\
\text { cells/ml. } \\
\text { b. The SEM images also showed that the increase in strength was } \\
\text { the result of the calcite precipitation } \\
\text { c. The highest compressive strength was found at a bacterial } \\
\text { concentration of } 1.5 \times 10^{8} \text { cells/ml However, the strength and } \\
\text { the durability reduced as the concentration increased } \\
\text { d. Bacterial specimens exhibited better performances than the } \\
\text { conventional concrete, in terms of durability and strength }\end{array}$ & $\begin{array}{l}\text { Oriola et al., } \\
(2018)\end{array}$ \\
\hline $\begin{array}{l}\text { Enterococcus } \\
\text { faecalis and } \\
\text { Bacillus cereus }\end{array}$ & $\begin{array}{ll}\text { a. } & \text { Direct } \\
\text { application } \\
\text { b. }\end{array}$ & $\begin{array}{l}\text { a. E. faecalis had high efficiency in increasing the compressive } \\
\text { and tensile strengths of concrete than B. cereus ( } 23 \% \text { vs. } \\
14.2 \% \text {, and } 13 \% \text { vs. } 8.5 \% \text {, respectively). } \\
\text { b. Both bacteria produced higher amount of calcite till their } \\
\text { curing periods. } \\
\text { c. The SEM images exhibited distinct amount of calcite crystals } \\
\text { and decrease in pore sizes. } \\
\text { d. From the EDX analysis, the highest percentage of calcium } \\
\text { constituent was determined. } \\
\text { e. Significant water penetration reduction was possible, by using } \\
\text { both of the bacterial sample. } \\
\text { f. Compared to conventional concrete, water absorption } \\
\text { reduced at } 3 \text { and } 5 \% \text { for } E \text {. faecalis and B. cereus, at } 28 \text { days age. }\end{array}$ & $\begin{array}{l}\text { Alshalif et al., } \\
\text { (2019) }\end{array}$ \\
\hline $\begin{array}{l}\text { Sporosarcina } \\
\text { pasteurii }\end{array}$ & 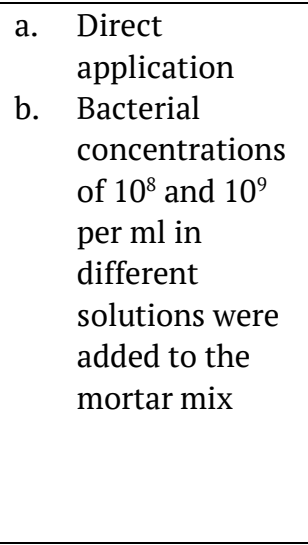 & $\begin{array}{l}\text { a. The effect of varying bacterial concentrations on cement- } \\
\text { sand mortar was significant } \\
\text { b. The addition of } S \text {. pasteurii had positive impact on } \\
\text { compressive and tensile strengths, due to the calcite } \\
\text { precipitation. } \\
\text { c. From SEM analysis, the growth of fibrous filler were observed } \\
\text { within the pores, due to the precipitation of calcite. } \\
\text { d. The mortar created with the } 10^{8} \text { cells/ml was filled with } \\
\text { narrow filler strand. } \\
\text { e. The increment in cells provided better results, i.e., } 4.9 \text { and } 4 \% \\
\text { compressive strength increment in NB and NH4-YE media, } \\
\text { respectively. This clearly indicated that the NH4-YE medium } \\
\text { did not have any influence. }\end{array}$ & $\begin{array}{l}\text { Al-Salloum et } \\
\text { al., (2016) }\end{array}$ \\
\hline Bacillus subtilis & $\begin{array}{ll}\text { a. } & \text { Direct } \\
\text { application } \\
\text { b. } & \text { Bacterial spores } \\
& \text { of } 10^{4}, 10^{5} \text {, and } \\
& 10^{6} \text { cells } / \mathrm{ml} \\
& \text { were directly } \\
& \text { added into } \\
\text { pulverized fly } \\
\text { ash medium }\end{array}$ & $\begin{array}{l}\text { a. The mortars having bacterial spores, calcium lactate, and urea } \\
\text { in pulverized fly ash medium, performed better in all aspects. } \\
\text { b. For water submersion, samples with } 10^{6} \text { cells } / \mathrm{ml} \text { showed } \\
\text { higher compressive strength increment at } 10.66 \text { and } 16.11 \% \\
\text { for } 3 \text { and } 7 \text { days, compared to the control mortar. } \\
\text { c. For submersion in } 5 \% \text { urea and } 1 \% \text { calcium lactate solutions, } \\
\text { samples with } 10^{5} \text { cells } / \mathrm{ml} \text { showed higher compressive } \\
\text { strength improvement at } 25.38 \text { and } 21.40 \% \text { for } 3 \text { and } 7 \text { days, } \\
\text { compared to the conventional mortar. } \\
\text { d. From flexural strength test, the stiffness recovery of the } \\
\text { original strength was achieved for the bacterial specimens, at } \\
\text { 34.85\%. } \\
\text { e. Based on water permeability test, bacterial spores were able to } \\
\text { heal the cracks to } 0.22 \text { mm width }\end{array}$ & $\begin{array}{l}\text { Nugroho et } \\
\text { al., (2015) }\end{array}$ \\
\hline
\end{tabular}


Table 2. Literature analysis of Bio-agent enriched laboratory-based research (Cont.)

\begin{tabular}{|c|c|c|c|}
\hline \multirow[t]{2}{*}{ Bio-agent used } & \multirow[t]{2}{*}{ Methodology } & Major outcomes & \multirow[t]{2}{*}{ References } \\
\hline & & $\begin{array}{l}\text { f. From XRD analysis, bacterial and control mortar had } \\
\text { 39.70/25.20\% calcite and 62.36/42.30\% crystallinity, } \\
\text { respectively. }\end{array}$ & \\
\hline Bacillus subtilis & $\begin{array}{l}\text { a. Direct } \\
\text { application } \\
\text { b. Bacterial } \\
\text { culture having } \\
\text { OD }_{600}=0.107, \\
0.2,0.637, \text { and } \\
1.221 \text { were } \\
\text { directly added } \\
\text { to the concrete } \\
\text { mix, as } 50 \% \\
\text { replacement of } \\
\text { water }\end{array}$ & $\begin{array}{l}\text { a. Concrete specimens containing } \mathrm{OD}_{600}=0.637 \text { showed better } \\
\text { performance. } \\
\text { b. Concrete Mix } 4 \text { with } \mathrm{OD}_{600}=0.637 \text { showed } 17.91 \text { and } 11.95 \% \\
\text { increment in compressive strength for } 20 \text { and } 30 \mathrm{MPa} \text { at } 28 \\
\text { days, compared to the conventional specimens. } \\
\text { c. For } \mathrm{OD}_{600}=0.637,12 \% \text { increment in split tensile strength was } \\
\text { also observed. } \\
\text { d. Approximately 6-9\% increment in pulse velocity was recorded } \\
\text { for concrete specimens with } 0.637 \text { optical density, at the age } \\
\text { of } 28 \text { days. } \\
\text { e. OD } 600=0.5 \pm 0.1 \text { was a good option for developing bacterial } \\
\text { concrete genera. }\end{array}$ & $\begin{array}{l}\text { Priyom et al., } \\
(2021)\end{array}$ \\
\hline $\begin{array}{l}\text { Sporosarcina } \\
\text { pasteurii }\end{array}$ & $\begin{array}{l}\text { a. } \begin{array}{l}\text { Encapsulation } \\
\text { method }\end{array} \\
\text { b. A protective } \\
\text { carrier was } \\
\text { developed for } \\
\text { bacteria, by } \\
\text { using calcium } \\
\text { sulphoaluminat } \\
\text { e cement } \\
\text { c. Microsilica of } 0, \\
20 \text { and } 40 \%, \\
\text { were added to } \\
\text { the concrete } \\
\text { mix }\end{array}$ & $\begin{array}{l}\text { a. The carrier acted as a support for the bacteria, ensuring } \\
\text { preservation for long duration. } \\
\text { b. The crack widths ranging from } 20-450 \mathrm{~mm} \text { were generated by } \\
\text { applying compressive load. } \\
\text { c. For visual observation of the cracks, a processing software } \\
\text { known as the "Image-Pro plus" was used. } \\
\text { d. Specimens having } 20 \% \text { silica fume with protective bacterial } \\
\text { spores showed better performance. } \\
\text { e. Self-healing of cracks with } 0.42 \mathrm{~mm} \text { width was obtained in } 28 \\
\text { days. } \\
\text { f. The regain ratio of compressive strength and water tightness } \\
\text { increased at } 130 \text { and } 50 \% \text { for bacterial specimens, compared } \\
\text { to plain mortar. }\end{array}$ & $\begin{array}{l}\text { Xu and } \\
\text { Wang, (2018) }\end{array}$ \\
\hline Bacillus & $\begin{array}{l}\text { a. Encapsulation } \\
\text { method } \\
\text { b. Mixture of } \\
\text { viable and } \\
\text { dormant } \\
\text { bacteria in } \\
\text { porous clay } \\
\text { particles }\end{array}$ & $\begin{array}{l}\text { a. Cracks were formed in concrete specimen slabs with } 10 \mathrm{~cm} \text { di } \\
\text { and } 2.5 \mathrm{~cm} \text { thickness, by the controlled application of } \\
\text { compressive and tensile stresses. A crack width of } 0.15 \mathrm{~mm} \\
\text { was also generated. } \\
\text { b. Cracks with } 0.15 \mathrm{~mm} \text { width and } 8 \mathrm{~cm} \text { length were totally } \\
\text { sealed. } \\
\text { c. All specimens containing bacterial spores and controlled } \\
\text { concretes showed } 100 \text { and } 33 \% \text { healing of cracks. }\end{array}$ & $\begin{array}{l}\text { Jonkers } \\
\text { (2011) }\end{array}$ \\
\hline $\begin{array}{l}\text { Bacillus } \\
\text { sphaericus }\end{array}$ & $\begin{array}{l}\text { a. Encapsulation } \\
\text { method } \\
\text { b. Melamine- } \\
\text { based capsule } \\
\text { was added to } \\
\text { the concrete } \\
\text { mix }\end{array}$ & $\begin{array}{l}\text { a. Bacterial spores were able to grow and germinate in high } \mathrm{pH} \\
\text { range. } \\
\text { b. Optimal pH range for growth was } 7-9 \text {. Although the growth } \\
\text { rate decreased at pH of } 10-11 \text {, it did not stop. } \\
\text { c. Crack width of } 0.97 \mathrm{~mm} \text { was healed by bacterial spores. } \\
\text { d. Crack healing ratio for bio samples was } 48 \text { to } 80 \% \text {. }\end{array}$ & $\begin{array}{l}\text { Wang et al., } \\
(2017)\end{array}$ \\
\hline $\begin{array}{l}\text { Shewanella and } \\
\text { E. coli }\end{array}$ & $\begin{array}{ll}\text { a. } & \text { Direct } \\
\text { application } \\
\text { b. } & \text { Seven different } \\
& \text { cell } \\
\text { concentration } \\
\text { ranging from } 10 \\
\text { to } 10^{7} \text { per ml } \\
\text { were directly } \\
\text { mixed with } \\
\text { water. }\end{array}$ & $\begin{array}{l}\text { a. Cell concentration was determined by developing } \mathrm{OD}_{620} \text { vs. } \\
\text { bacterial cell numbers, standard curve. } \\
\text { b. Mortar specimens containing Shewanella spores of } 10^{5} \\
\text { cells/ml showed } 25 \% \text { increment in compressive strength, than } \\
\text { the conventional concrete. } \\
\text { c. For } E \text {. coli, the increment in the compressive strength were } \\
\text { less than } 1 \% \text {, compared to the conventional concrete. }\end{array}$ & $\begin{array}{l}\text { Ghosh et al., } \\
(2005)\end{array}$ \\
\hline
\end{tabular}


Table 2. Literature analysis of Bio-agent enriched laboratory-based research (Cont.)

\begin{tabular}{|c|c|c|c|}
\hline Bio-agent used & Methodology & Major outcomes & References \\
\hline $\begin{array}{l}\text { Sporosarcina } \\
\text { Pasteurii }\end{array}$ & 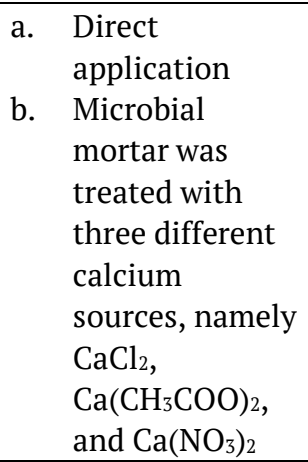 & $\begin{array}{l}\text { a. Samples treated by calcium acetate showed better result in } \\
\text { compressive strength increment, which was } 2.45,2.58 \text {, and } \\
1.32 \text { times higher than other samples. } \\
\text { b. Samples of bacterial mortar with calcium acetate showed } \\
\text { better tensile strength, which was } 2.4 \text { and } 3.0 \text { times than } \\
\text { chloride and nitrate samples respectively. } \\
\text { c. SEM and XRD analysis showed that the use of } \mathrm{Ca}\left(\mathrm{CH}_{3} \mathrm{COO}\right)_{2} \text { as } \\
\text { calcium source for MICP, improved the mechanical properties } \\
\text { and durability of the microbial mortar. }\end{array}$ & $\begin{array}{l}\text { Zhang et al., } \\
(2015)\end{array}$ \\
\hline $\begin{array}{l}\text { Bacillus } \\
\text { sphaericus }\end{array}$ & $\begin{array}{l}\text { a. Encapsulation } \\
\text { method } \\
\text { b. Bacterial spores } \\
\text { were } \\
\text { encapsulated } \\
\text { into hydrogels, } \\
\text { and } \\
\text { incorporated } \\
\text { into the } \\
\text { specimens }\end{array}$ & $\begin{array}{l}\text { a. Prism specimens were subjected to multiple cracking by } \\
\text { tensile load, with an average crack width of } 150 \mathrm{~mm} \text {. } \\
\text { b. Maximum healing efficiency was observed in the specimens } \\
\text { with bio-hydrogels, as } 0.5 \mathrm{~mm} \text { crack width was successfully } \\
\text { healed. Approximately } 40-90 \% \text { healing ratio was also } \\
\text { observed under wet-dry cycle. } \\
\text { c. For non-bio hydrogel specimens, the healing width was } 0-0.3 \\
\text { mm. } \\
\text { d. Based on bacterial and control specimens, water permeability } \\
\text { decreased by } 68 \text { and } 15-55 \% \% \text { in average. }\end{array}$ & $\begin{array}{l}\text { Wang et al., } \\
(2014)\end{array}$ \\
\hline Bacillus & 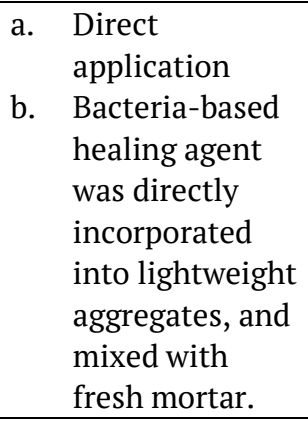 & $\begin{array}{l}\text { a. The liquid-tightness of mortar matrix with and without } \\
\text { bacterial spores were evaluated through water permeability } \\
\text { test, in both water immersion and wet-dry cycles. } \\
\text { b. Water tightness of samples with and without bacterial spores } \\
\text { were not different when immersed in water. } \\
\text { c. During wet-dry cycles, samples with bacterial spores showed } \\
\text { better performance than the control concrete. } \\
\text { d. For bacterial samples, } 96 \% \text { of water tightness was achieved at } \\
\text { day } 56 \text {. }\end{array}$ & $\begin{array}{l}\text { Tziviloglou et } \\
\text { al., (2016) }\end{array}$ \\
\hline $\begin{array}{l}\text { Bacillus } \\
\text { mucilaginous and } \\
\text { Brewers yeast }\end{array}$ & $\begin{array}{ll}\text { a. } & \begin{array}{l}\text { Direct } \\
\text { application }\end{array} \\
\text { b. } & \text { Bacterial spores } \\
\text { with and } \\
\text { without } \\
\text { nutrient were } \\
\text { added to } \\
\text { cement and } \\
\text { water, mixed } \\
\text { with prism and } \\
\text { cylinder } \\
\text { specimens } \\
\end{array}$ & $\begin{array}{l}\text { a. Cracks were formed by bending test. } \\
\text { b. Approximately } 0.4-0.5 \mathrm{~mm} \text { with cracks were made by } \\
\text { embedded method. } \\
\text { c. For nutrient enriched bacterial samples, cracks with width of } \\
0.4-0.5 \mathrm{~mm} \text { were repaired after recurring for } 28 \text { days. } \\
\text { d. For nutrient enriched bacterial samples, crack area repair } \\
\text { ratio was } 87.5 \% \text {. } \\
\text { e. The combination of ceramsite, brewer yeast, and Bacillus } \\
\text { Mucilaginous, were able to reduce water permeability } \\
\text { coefficient from } 7.9-8.3 \times 10^{-5} \mathrm{~m} / \mathrm{s} \text { to } 0.8 \times 10^{-7} \mathrm{~m} / \mathrm{s} \text {, after } 49 \text { days } \\
\text { of healing period. }\end{array}$ & $\begin{array}{l}\text { Chen et al., } \\
(2016)\end{array}$ \\
\hline Bacillus subtilis & 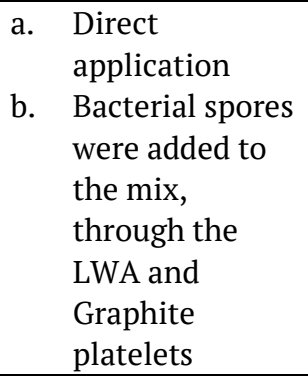 & $\begin{array}{l}\text { a. Bacteria immobilized in graphite nano platelets provided } \\
\text { better result in pre-cracked specimens, at } 3 \text { and } 7 \text { days old. } \\
\text { b. Specimens immobilized in LWA were more effective in } \\
\text { samples pre-cracked at } 14 \text { and } 28 \text { days old. } \\
\text { c. Higher crack width was healed by bacterial samples with LWA, } \\
\text { at } 0.53 \text { mm. } \\
\text { d. Approximately } 12 \% \text { increment in compressive strength was } \\
\text { observed for LWA immobilized specimens. }\end{array}$ & $\begin{array}{l}\text { Khaliq et al., } \\
\text { (2016) }\end{array}$ \\
\hline
\end{tabular}


8.2 Application of bio-engineered mortar and concrete in structural elements

Although most of these studies were laboratorybased, a few conducted in the last five years were still related to the application of bio-cultures as healers and strength increasers in practical structural elements.

Mors and Jonkers (2019), conducted several practical implementations on bio-engineered mortar and concrete. This was the largest practical study that mainly focused on the ability of bio-cultures, towards crack healing within a realistic environment. It also included two repair mortar and concrete construction demonstration projects, where a representative from the Bacillus genus was used as a healing agent.

Self-healing mortar: This was applied into a damaged reinforced concrete column (Figure 7), and cracked with active leaking garage basement walls, which were located at $20 \mathrm{~m}$ below ground (Figure 8). To evaluate the performance of the self-healing mortar, visual determination of water tightness and hammer-knocking test was conducted with desired intervals. In addition, biennially monitoring for two subsequent years showed that the repaired patches were watertight, with the observation of sound bonding in both conditions.

Self-healing concrete: The research team carried out two full-scale demonstrator projects, by using self-healing concrete. The first project was conducted on the construction of a wastewater purification tank of 7 X 2.5 X $0.15 \mathrm{~m}$ (Figure 9), while the second was carried out on a rectangular water reservoir of $47 \mathrm{~m}$ long X $5 \mathrm{~m}$ high dimension, where the south and east-facing walls were fully constructed by using selfhealing concrete (Figure 10).

Based on the wastewater purification tank, a 10 $\mathrm{kg}$ healing agent per $\mathrm{m}^{3}$ concrete mix was applied. The result showed that the tank completed three years of successful operation till September 2019, with no cracks or degradation on the surface. For the water reservoir, a $5 \mathrm{~kg} / \mathrm{m}^{3}$ self-healing agent was added to the concrete mix. Although the south-facing wall was more critical for cracking, the implementation of this method showed that no breaches were observed. However, minor cracks were found in the northfacing wall, where self-healing agent was not applied.

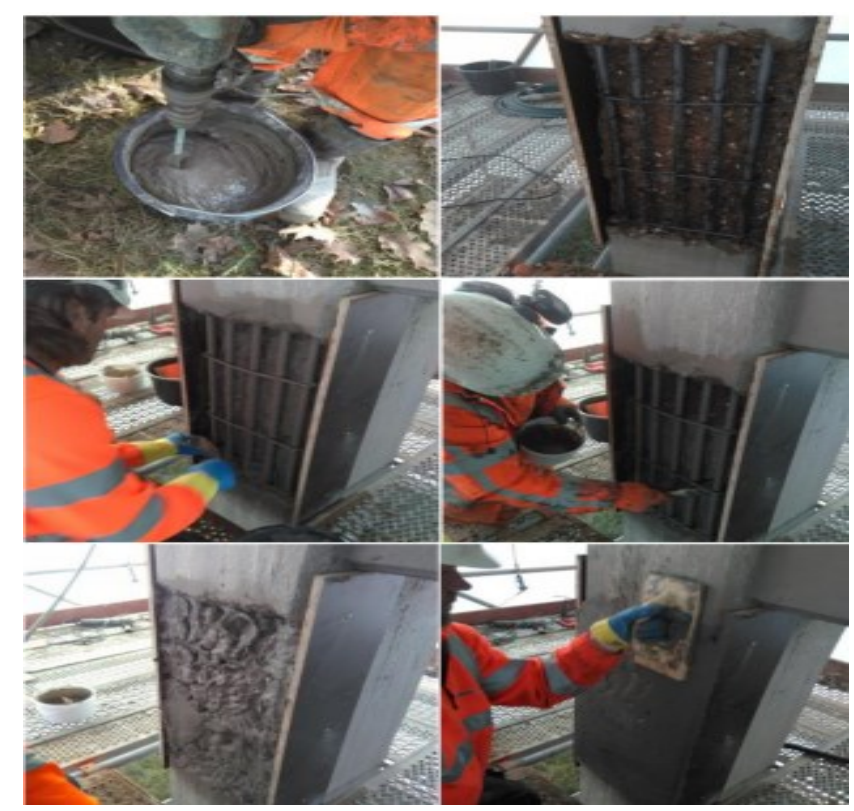

Figure 7. Application of bacteria-based self-healing repair mortar on steel reinforced concrete column (Mors \& Jonkers, 2019).

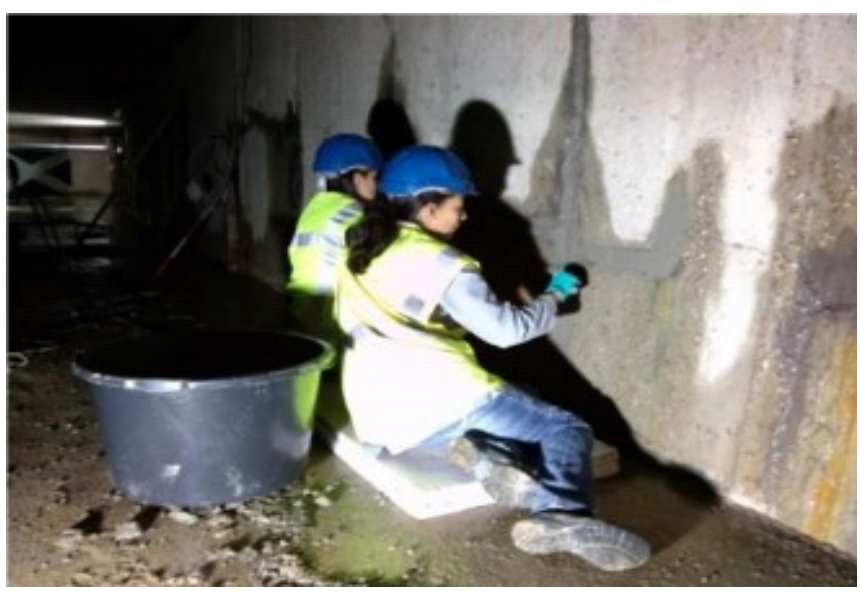

Figure 8. Application of bacteria-based self-healing repair mortar on actively leaking cracked concrete basement walls (Mors \& Jonkers, 2019). 


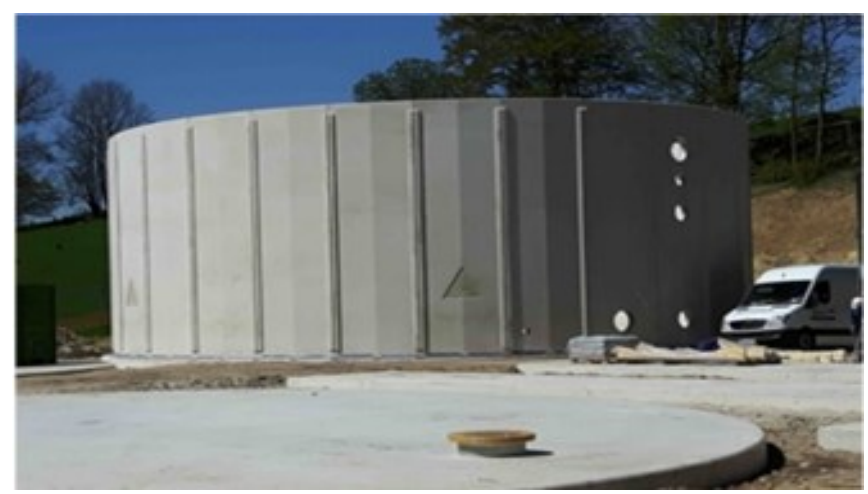

Figure 9. Prefabricated wastewater treatment tank by using self-healing concrete (under construction) (Mors \& Jonkers, 2019).

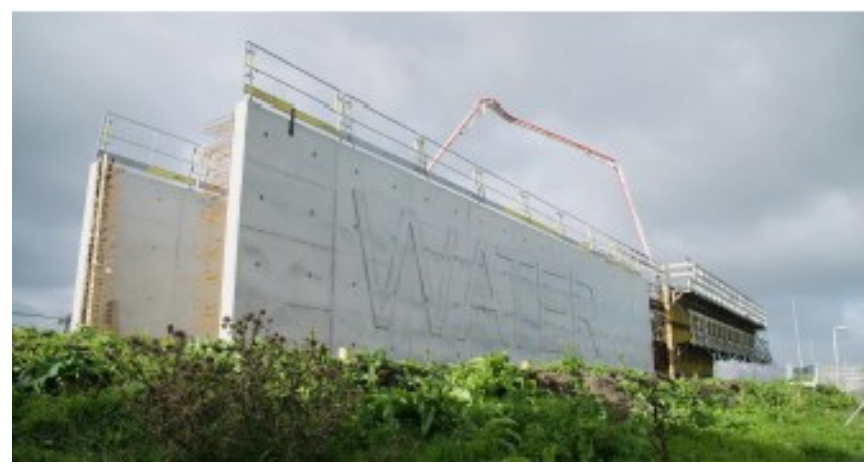

Figure 10. Full scale demonstrator nn situ cast selfhealing concrete water reservoir (Mors \& Jonkers, 2019).

Zhang and Qian (2020) conducted the engineering application of self-healing concrete on ship lock walls, for practical outcomes. This study used Bacillus mucilaginous and calcium nitrate powder for the purpose of the process, as a dry-spray method was utilized for making microbial particle. Also, both laboratory-based and practical analysis were also conducted, respectively. In the laboratory-based analysis, there was no significant difference between the workability levels of the control and microbial structures, as the compressive strength of selfhealing concrete was slightly lower than the conventional type at the age of 28 days. During this period, $0.543 \mathrm{~mm}$ artificial crack was entirely healed by the self-healing material (Figure 11), as $2 \theta=29.49^{\circ}$ and $29.41^{\circ}$ also indicated the production of minerals.

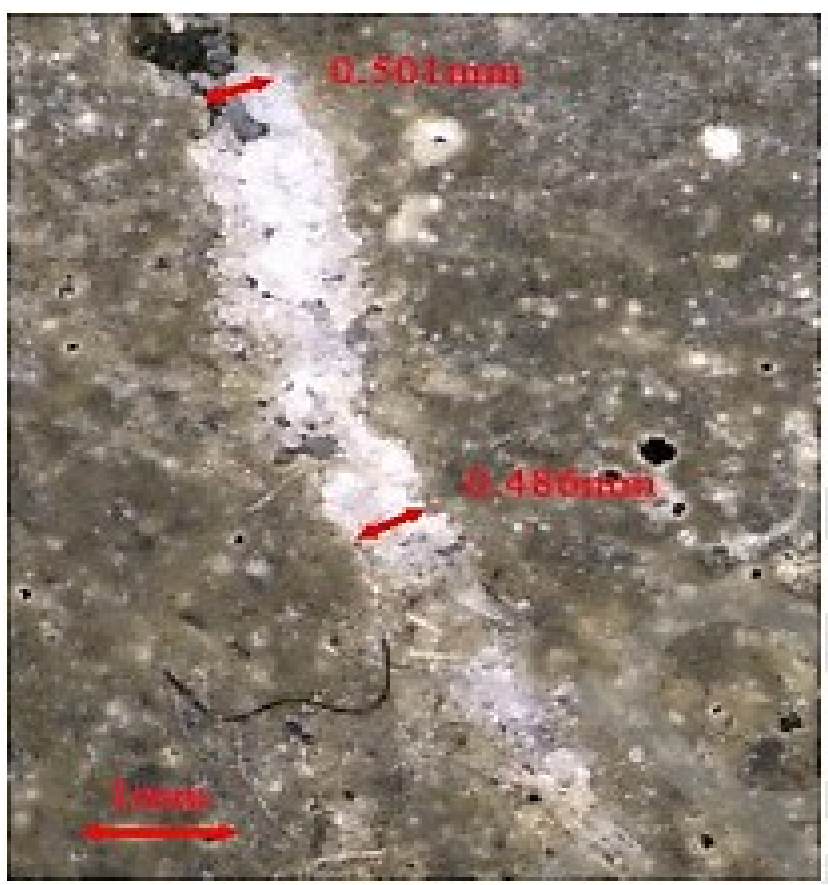

Figure 11. Sealing of $0.543 \mathrm{~mm}$ crack of laboratory specimen after 28 days of curing (Zhang and Qian, 2020)

Figure 12 shows the whole process of generating and applying self-healing concrete on the ship lock chamber. Based on temperature stress and shrinkage, cracks were generated on both the normal and self-healing concrete gates of the side wall.

At the age of 65 days, the cracks on the surface of the normal concrete were not healed. However, the generated breaches on the self-healing material were fully healed by calcite precipitation (Figure 13). In addition, the connectivity of the cracks were completely blocked on the bacterial enriched wall, as the leakages of water were not observed.

Mullem et al. (2020), conducted a large scale application of self-healing concrete by directly mixing $\mathrm{MUC}^{+}$with the material (Figure 14). This compound $\left(\mathrm{MUC}^{+}\right)$was obtained from the combination of ureolytic culture with anaerobic granular bacteria. 
A

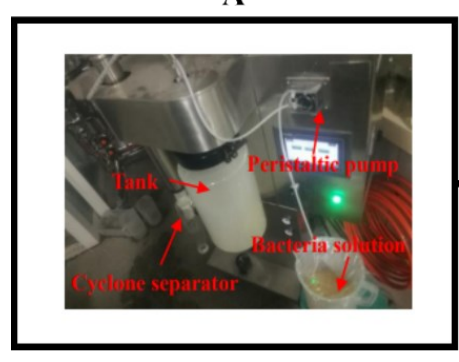

E
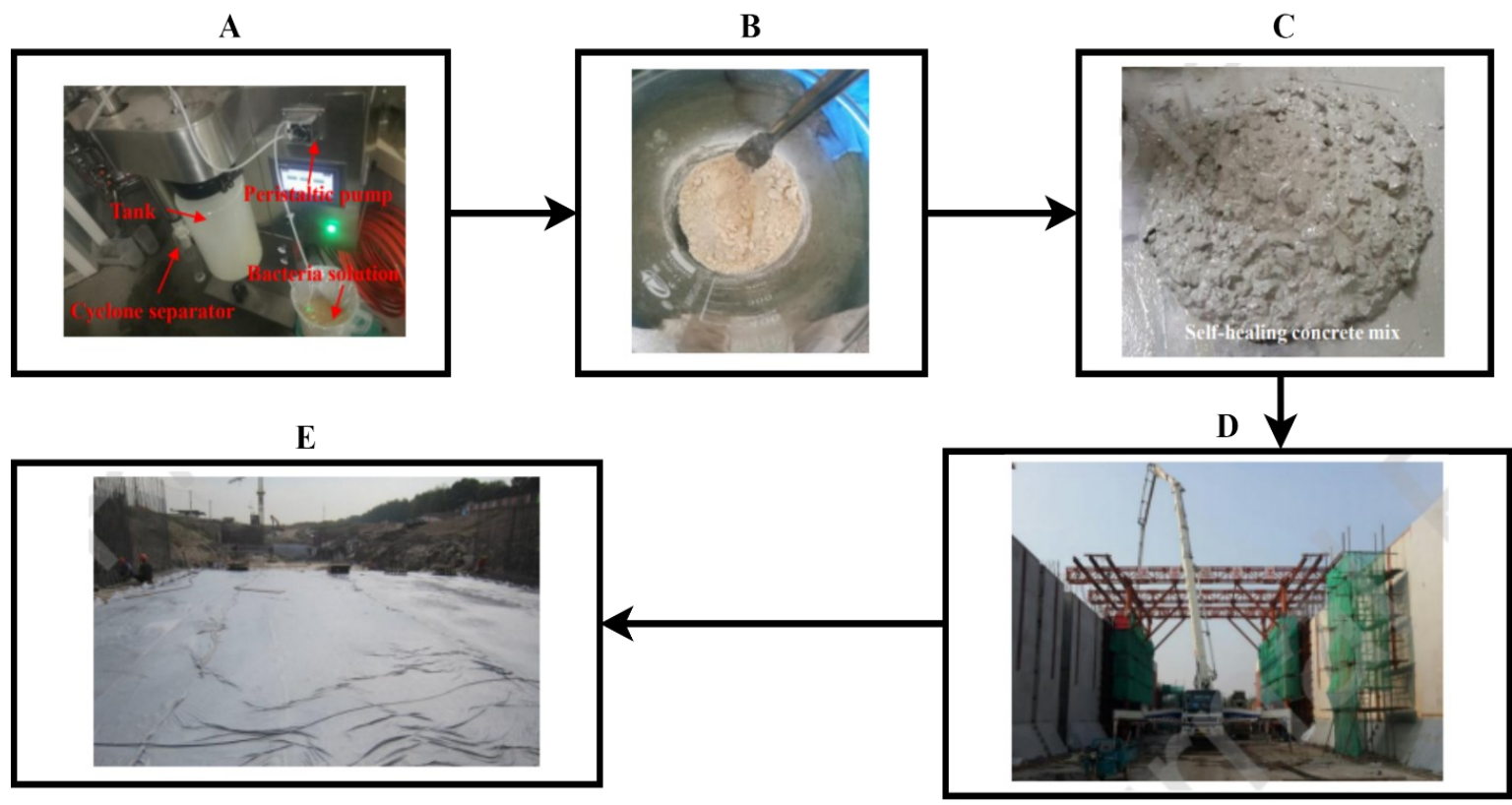

Figure 12. Whole process of the construction of bacteria-based self-healing ship lock wall: (A) Spray drying of bacterial sample, (B) Spore powder, (C) Self-healing concrete mix, (D) Pouring of self-healing concrete, (E) Curing of self-healing concrete (Zhang and Qian, 2020).
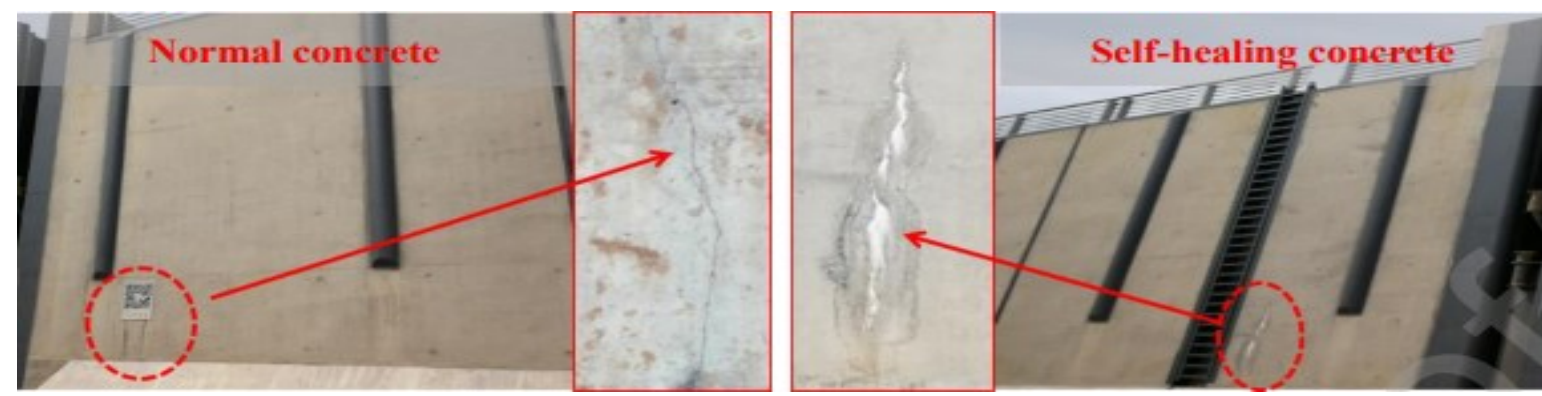

Figure 13. Comparison of self-healing effects of ship lock wall made by normal concrete (left) and made by bacterial concrete (right) (Zhang and Qian, 2020).
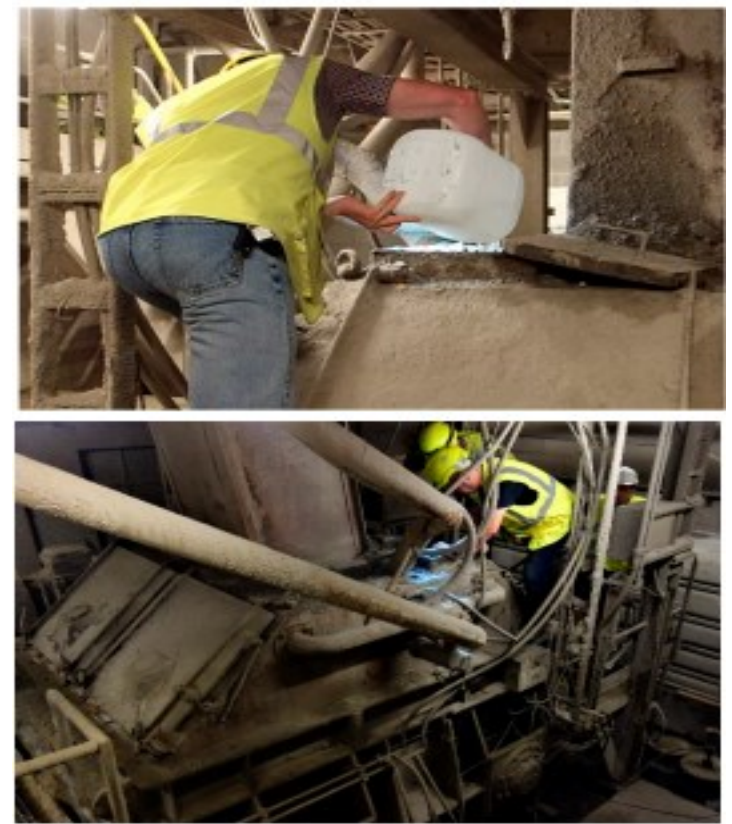

Figure14. Addition of bacterial agent, urea and calcium nitrate tetrahydrate through inspection hatch above industrial concrete mixer (Mullem et al., 2020).
Furthermore, the roof slab of a drainage pipe inspection pit (Figure 15) and laboratory prism specimens were casted by the same bacterial concrete mix (Figure 16). In the self-healing concrete mix, two different water-reducing plasticizers and one mass (\%) of bio-agent were added. From the laboratory analysis, a significant amount of strength was increased at 93 days, through the addition of the self-healing agent, as increment was also observed to be 9.7 MPa.

Based on the laboratory specimens, cracks were created through the application of the tensile stress, as widths varying between $0.52-0.58 \mathrm{~mm}$ were perfectly sealed during the healing analysis. For bottom cracks with $245 \mu \mathrm{m}$ width, $86.3 \%$ closure was observed, as the formation of stalactites was also found during the wet-dry cycle analysis (Figure 17). 
The roof slab was also installed in the inspection room after five weeks of casting. After this, an onsite inspection was conducted after one year of casting, as no cracking sign was observed at the bottom of the slab. Approximately $30 \%$ of the slab top was covered by large condensation drops, which indicated that it was is in a favourable condition to heal the cracks (Figure 18).

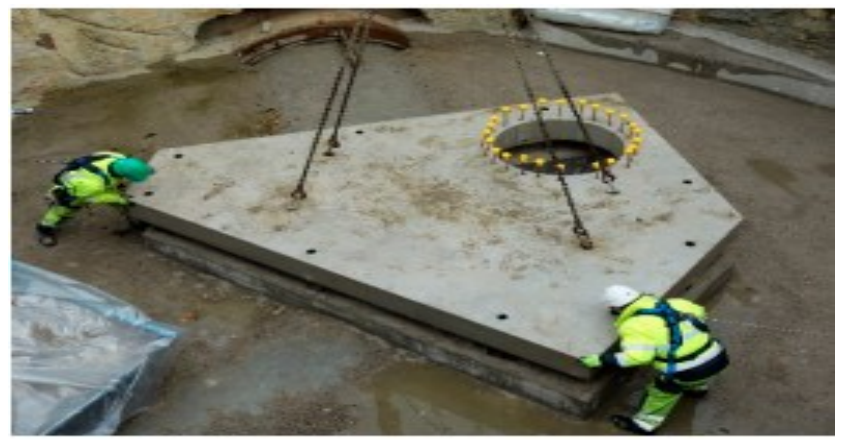

Figure 15. Roof slab made by bio-engineered concrete (Mullem et al., 2020).

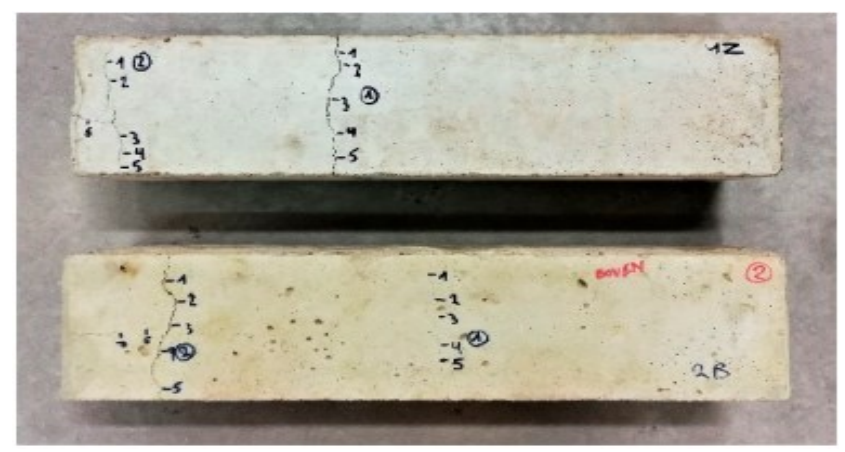

Figure 16. Laboratory prism specimens made by bioengineered concrete (Mullem et al., 2020).

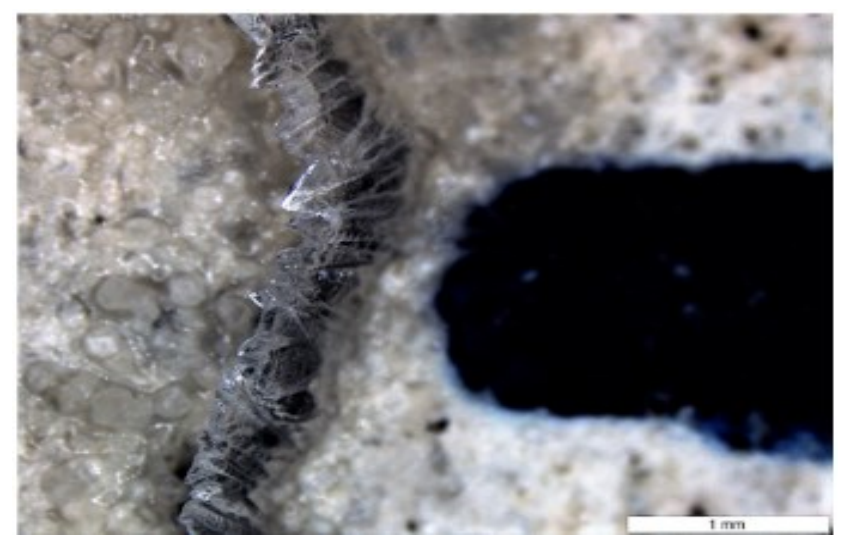

Figure 17. Formation of stalactites on a crack location of a prism specimen subjected to W/D cycles (Mullem et al., 2020).

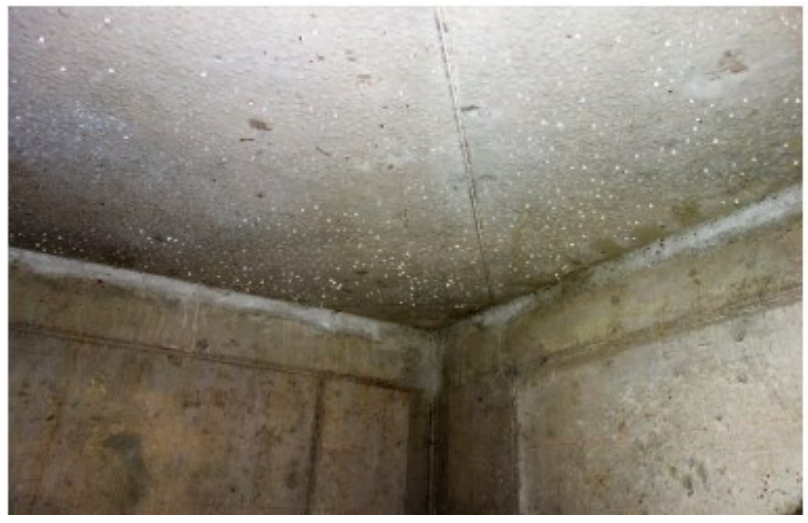

Figure 18. Condensation on the bottom side of the roof slab showing favorable condition for self-healing (Mullem et al., 2020).

\section{HEALING CAPABILITY OF BIO-ENGINEERED CONCRETE AND TYPES OF CRACK HEALED}

Based on the literature review, the maximum crack width completely sealed by the bioengineered concrete is $0.97 \mathrm{~mm}$. The healing of crack widths ranging from 0.3-0.6 mm was also observed in several pieces of the study, which had been reviewed in Table 2 . In a practical situation, the healing capacity depended on the surrounding environment (Mullem et al., 2020). When this environment supply sufficient moisture and oxygen, the healing capability of bio-engineered concrete increases. This material is capable of healing cracks to a width of $1 \mathrm{~cm}$ in a practical situation (Zhang and Qian, 2020). In this case, the selection of bio-cultures played a vital role, as the use of calcite reagent also increased healing capability. Most of the studies focused on the amount of crack width, healed with complete crack closure by the bioengineered concrete. However, Jonkers (2011), tried to focus on the length of crack that was efficiently sealed by the material. The study also showed that approximately $8 \mathrm{~cm}$ crack length was completely healed by the bio-engineered concrete, as the healing capability of bio-agent generally varied from 0.5 to $0.8 \mathrm{~mm}$ in practical situations (De Belie and Wang, 2015).

Concrete structures are also susceptible to various cracks, with most of them occuring before and after hardening. From the literature analysis, bio-engineered concrete mainly focused on the cracks generated after the hardening of the structural specimens. Several 
pre-hardening cracks, such as construction movement and plastic breaches, were also healed by bio-engineered concrete.

The crack types healed by this method were often a topic of great interest among experts, as the implementation and further study in this field were more straightforward when summarized. Based on the literature reviewed, a diagram showing the crack type healed by bio-engineered concrete is shown in Figure 19.

\section{PRIORITY OF BIO-GENUS USED IN THE RESEARCH STUDY}

According to the reviewed literatures, more than $80 \%$ of the studies were carried out by adopting a representative from the genus-Bacillus. This was due to its tremendous ability to precipitate carbonate during harsh environment. In addition, the usage of various bio-genus is shown in Figure 20, through the representation of a bar chart.

Type of cracks that can be healed by Bio-engineered concrete

Before hardening of concrete
(a)Construction movement cracks
(b)Plastic shrinkage cracks
(c)Water penetration cracks in mortar

After hardening of concrete

(a)Compressive stress cracks

(b)Tensile stress cracks

(c)Bending stress cracks

(d)Temperature variation cracks

(e)Shrinkage cracks

(f)Freeze and thaw cracks

(g)Flexural stress cracks

Figure 19. Type of crack healed by bio-engineered concrete.

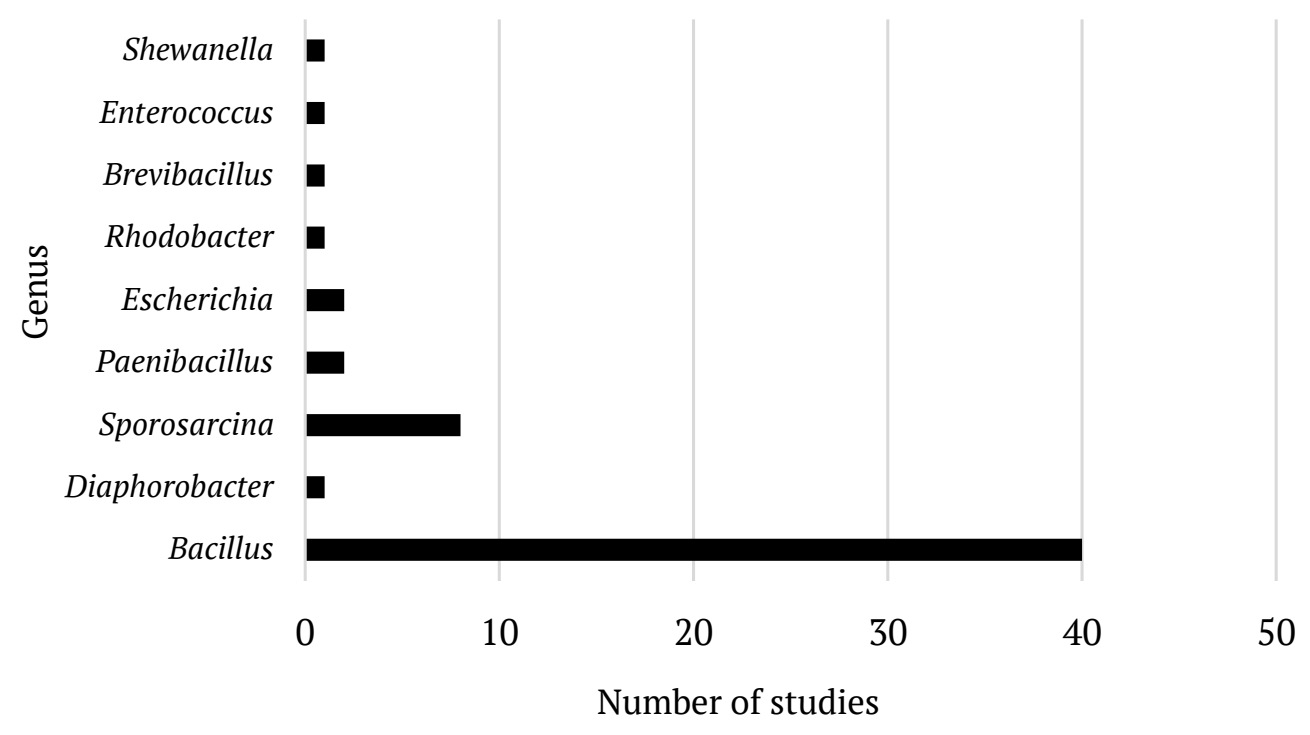

Figure 20. Usage of different bio-genus in reviewed literatures. 


\section{APPLICATION OF BIO-ENGINEERED CONCRETE}

Sustainable urban amenities are very important for the better economy of a country, as most of the industrial works are infrastructurally related. This is because a small improvement on the durability of infrastructure has the ability to provide a larger result in the economy. Therefore, the use of bio-engineered concrete is becoming more popular in Structural Engineering. The roles and functions of this method are as follow,

- Sealing of cracks in concrete structure: Bio-engineered concrete are an excellent option for making durable structures, due to their bio-mineralization abilities.

- Mechanical strength increaser by conducting reaction with cement-sand matrix.

- Preparation of less permeable concrete: Bacteria within the concrete reduce void volumes, leading to more compaction and less permeability.

- Enhancement of resistance towards freeze-thaw action.

- Construction of low-cost durable housing.

- Durable rigid pavement preparation.

- Effect on sea-shore structures: It protects the structure from corrosion and prevents the deformation of rebar.

\section{EFFECT OF BIO-AGENT ON THE PROPERTIES} OF CONCRETE

- Compressive strength: The use of biocultures help in filling the pores between cement-sand microstructures, in order to acquire more compressive strength and become denser. According to Table 2, approximately $40 \%$ increase in this strength was observed through the use of bacteria.

- Reduction of permeability: Calcium carbonate helps in filling and reducing the pores and permeability of concrete specimens, respectively. Also, the permeability of bio-concrete is less than half, compared to the conventional structure.

- Setting time: Based on the different bioagent solutions, the set time of the concrete mix is accelerated or delayed. In addition, calcium lactate delayed this time, while $\mathrm{Ca}(\mathrm{HCOO})_{2}$ and $\mathrm{Ca}\left(\mathrm{NO}_{3}\right)_{2}$ (Calcium Formate and Calcium Nitrate) accelerated it (Jonkers et al., 2010).

- Development of the microstructure: The SEM and XRD analysis indicated that the application of bio-agent caused calcite precipitation on the concrete microstructure, which eventually enriched the property of the structural specimens (Jagadeesha et al., 2013; Jonkers and Schlangen, 2007).

- Self-healing: The use of bio agent enriches the ability of concrete, in order to heal cracks. From the literature analysis, the utilization of bacteria healed approximately $1 \mathrm{~cm}$ concrete crack width.

\section{RECCOMENDATION FOR FURTHER STUDY}

- Any new invention or improvement of the existing methodology in the construction industry needs a lot of practical research. Bio-concrete as a recent phenomenon is the most promising solution for durable structures. However, the long-term effect of this method is not well recognized. Previously, several studies were carried out on this topic, with most of them being laboratory-based. Only a few demonstration project was conducted to assess the suitability of this new method. Therefore, large scale practical implementation and the regular inspection to sort out any problem should be the next step.

- The selection of bio-agent is also a matter of great concern, due to the difference in the climatic and environmental situation suitable for the microorganisms. Therefore, separation and categorization 
on various exposure conditions should be an important issue in the future.

- Based on practical implementation, bioconcrete should also be cost effective, with the budget mainly depending on the selection of bio-cultures. Therefore, the cost of the project should be focused on various exposure conditions.

\section{CONCLUSION}

Bio-engineered concrete is becoming a popular topic for research purposes. In this study, several publications focusing on the performance of bioengineered concrete were reviewed. Based on the literature reviewed, it was found out that such type of concrete are useful for harsh environment where density and compactness of the concrete microstructure is needed. Bioengineered concrete significantly improved the lifetime of construction, by reducing the repair and replacement costs. Therefore, the additional investment in the method was accurately worth the risk. In addition, future research on bioengineered concrete should understand the costeffectiveness and long-term effects.

\section{DISCLAIMER}

The authors declared no conflict of interest

\section{AVAILABILITY OF DATA AND MATERIALS}

All data are available from the author.

\section{ACKNOWLEDGEMENT}

The authors are grateful for the supports provided by Suborno Debnath and Rayhan Bin Ahmed from Memorial University of Newfoundland, Canada, and also Md. Ibrahim Mostazid, PG student at the University of Tokyo, Japan.

\section{REFERENCES}

Abo-El-Enein, S. A., Ali, A. H., Talkhan, F. N., \& Abdel-Gawwad, H. A. 2013. Application of microbial biocementation to improve the physico-mechanical properties of cement mortar. HBRC Journal, 9, pp. 36-40.
Achal, V., Mukherjee, A., \& Reddy, M.S. 2010. Microbial Concrete: way to enhance the durability of building structures. Journal of Materials in Civil Engineering. Vol. 23, pp. 730734.

Alazhari, M., Sharma, T., Heath, A., Cooper, R., \& Paine, K. 2018. Application of expanded perlite encapsulated bacteria and growth media for self-healing concrete. Construction and Building Materials. Vol. 160, pp.610-619. doi: 10.1016/j.conbuildmat.2017.11.08.

Al-Salloum, Y., Abbas, H., Sheikh, I. Q., Hadi, S., Alsayed, S., \& Almusallam, T. 2017. Effect of some biotic factors on microbially-induced calcite precipitation in cement mortar. Saudi Journal of Biological Sciences. Vol. 24 (2), pp. 286294. doi: 10.1016/j. sjbs.2016.01.016.

Alshalif, A. F., Irwan, J. M., Othman, N., AlGheethi, A., \& Khalid, F.S. 2019. Improvement of mechanical properties of bio-concrete using Enterococcus faecalis and Bacillus cereus. Environmental Engineering Research. 24, pp. 630637. doi: 10.4491/eer.2018.306.

Anbu, P., Kang, C, Shin, Y., \& So., J. 2016. Formations of Calcium Carbonate Minerals by Bacteria and its Multiple Applications: Review. Springer Plus. 5:250. doi: 10.1186/s40064-0161869-2.

Andalib, R., Majid, M. Z. A., Hussin, M. W., Ponraj, M., Keyvanfar, A., Mirza, J., \& Lee, H. S. 2016. Optimum concentration of Bacillus megaterium for strengthening structural concrete. Construction and Building Materials. 118, pp. 180-193.

Balam, H. N., Mostofinejad, D., \& Eftekhar, M. 2017. Effects of bacterial remediation on compressive strength, water absorption, and chloride permeability of lightweight aggregate concrete. Construction and Building Materials. Vol. 145, pp. 107-116. doi: 10.1016/j. conbuildmat.2017.04.003.

Beltran, M.G. \& Jonkers, H. M. 2015. Crack SelfHealing Technology Based on Bacteria. Journal of 
Ceramic Processing Research, 2015. 16(1), pp. 3339.

Castro-Alonso, Montañez-Hernandez, Lilia, Muñoz, María, Franco, Mariel, Narayanasamy, R., \& Balagurusamy, N. (2019). Microbially Induced Calcium Carbonate Precipitation (MICP) and Its Potential in Bioconcrete: Microbiological and Molecular Concepts. Frontiers in Materials. 6. 126. doi: 10.3389/fmats.2019.00126.

Chen, H., Qian, C., \& Huang, H. 2016.Selfhealing cementitious materials based on bacteria and nutrients immobilized respectively. Construction and Building Materials, 126, pp. 297-303

De Belie, N. 2016. Application of bacteria in concrete: A critical evaluation of the current status. RILEM Technical Letters, 10, pp. 56-61. doi: 10.21809/rilemtechlett.2016.14.

De Belie, N., \& Wang, J. 2015. Bacteria-based repair and self-healing of concrete, Journal of Sustainable Cement-Based Materials, 5 (1-2), pp. 35-36. doi: 10.1080/21650373.2015.1077754.

De Muynck, W., Cox, K., Belie, N. D., \& Verstraete, W. 2008. Bacterial carbonate precipitation as an alternative surface treatment for concrete. Construction and Building Materials, 22(5), pp. 875-885.

Dhami, N.K., Reddy, M.S., \& Mukherjee, A. 2013. Bacillus megaterium mediated mineralization of calcium carbonate as biogenic surface treatment of green building materials. World Journal of Microbiology and Biotechnology (Formerly MIRCEN Journal of Applied Microbiology and Biotechnology). Vol. 29, pp. 2397-2406. doi: 10.1007/s11274-013-1408-z.

Gandhimathi, A., Suji, D., \& Elayarajah, B. 2015. Bacterial concrete: Development of concrete to increase the compressive and split-tensile strength using Bacillus sphaericus. International Journal of Applied Engineering Research. 10, pp. 7125-7132.

Ghosh, P., Mandal, S., Chattopadhyay, B. D., \& $\mathrm{Pal}$, S. 2005. Use of microorganism to improve the strength of cement mortar. Cement and Concrete Research, 35(10), pp. 1980-1983. doi:10.1016/j.cemconres.2005.03.005.

Hassan, M., Milla, J., Rupnow, T., \& Soysal, A. 2019. Self-Healing concrete using encapsulated bacterial spores in a simulated hot subtropical climate. Report of Tran-SET Project No. 18CLSU02

Islam, S. M., Sinha, T., \& Uddin, M. K2019. An experimental investigation on improvement of concrete strength using bacterial approach. In: $4^{\text {th }}$ International Conference on Advances in Civil Engineering 2018, CUET. pp. 683-688.

Jagadeesha, K.B.G., Prabhakara, \& Pushpa, H.. 2013. Effect of bacterial calcite precipitation on compressive strength of mortar cubes. International Journal of Engineering and Advanced Technology. 2. pp. 486-491.

Jagannathan, P., Narayanan, K. S. S., Arunachalam, K. D., \& Annamalai, S. K. 2018. Studies on the mechanical properties of bacterial concrete with two bacterial species. Materials Today: Proceedings. 5. pp. 8875-8879. doi: 10.1016/j.matpr.2017.12.320.

Jonkers, H. 2011. Bacteria-based self-healing concrete. Heron. 56.

Jonkers, H. M., \& Schlangen, E. 2007. Selfhealing of cracked concrete: A bacterial approach. In: Proceedings of the 6th International Conference on Fracture Mechanics of Concrete and Concrete Structures, 3, pp.1821-1826.

Jonkers, H. M., Thijssen, A., Muyzer, G., Copuroglu, O., \& Schlangen, E. 2010. Application of bacteria as selfhealing agent for the development of sustainable concrete. Ecological engineering, 36(2), pp. 230-235.

Joshi, S., Goyal, S., Mukherjee, A., \& Reddy, M. S. 2017. Microbial Healing of Cracks in Concrete: A Review. Journal of Industrial Microbiology and Biotechnology, 44, pp. 1511-1525.

Khaliq, W., \& Ehsan, M. B. 2016.Crack healing in concrete using various bio influenced self- 
healing techniques. Construction and Building Materials, 102, pp. 349-357. doi: 10.1016/j.conbuildmat.2015.11.006

Le Métayer-Levrel, G., Castanier, S., Orial, G., Loubière, J.-F., \& Perthuisot, J.-P. 1999. Applications of bacterial carbonatogenesis to the protection and regeneration of limestones in buildings and historic patrimony. Sedimentary Geology. Vol. 26, pp. 25-34.

Ling, H., \& Qian, C. 2017. Effects of self-healing cracks in bacterial concrete on the transmission of chloride during electromigration. Construction and Building Materials. 144, pp. 406-411. doi: 10.1016/j.conbuildmat.2017.02.160.

Mors, R., \& Jonkers, H. M. 2019. Bacteria-Based Self-Healing Concrete: Evaluation of Full Scale Demonstrator Projects. RILEM Tech Lett 2019, 4, 138-144.

Mullem, T., Gruyaert, E., Caspeele, R., \& De Belie, N. 2020. First Large Scale Application with Self-Healing Concrete in Belgium: Analysis of the Laboratory Control Tests. Materials. 13. 10.3390/ma13040997.

Nguyen, T.H., Ghorbel, E., Fares, H., \& Cousture, A. 2019. Bacterial self-healing of concrete and durability assessment. Cement and Concrete Composites. 104. pp. 103340. doi: 10.1016/j.cemconcomp.2019.103340.

Nosouhian, F., Mostofinejad, D., \& Hasheminejad, H. 2015. Concrete durability improvement in a sulfate environment using bacteria. Journal of Materials in Civil Engineering, 28. doi: 10.1061/ (ASCE)MT.1943-5533.0001337.

Nugroho, A., Satyarno, I., \& Subyakto, S. 2015. Bacteria as Self-Healing Agent in Mortar Cracks. Journal of Engineering and Technological Sciences. 47. pp. 279-295.

Oriola, F., Sani, J.E., \& Adah, A.M. 2018. Evaluation of the effect of Bacillus Pumilus precipitate on the strength and durability of concrete. Civil and Environmental Research. Vol. 10, pp. 1-10.
Paine, K., Alazhari, M., Sharma, T., Cooper, R., \& Heath, A. 2016. Design and performance of bacteria-based self-healing concrete. In: M R Jones, M D Newlands, J E Halliday, L J Csetenyi, L Zheng, M. J. McCarthy, \& T D Dyer (Eds.), The 9th International Concrete Conference 2016: Environment, Efficiency and Economic Challenges for Concrete. pp. 545-554.

Priyom, S. N., Islam, M., \& Islam, S. 2018. An experimental investigation on the performance of bacterial concrete. In: $4^{\text {th }}$ International Conference on Advances in Civil Engineering, CUET, pp. 392-397.

Priyom, S. N., Islam, M. M., \& Shumi, W. 2021. The Utilization of Bacillus Subtilis Bacteria for Improving Mechanical Properties of Concrete. Journal of the Civil Engineering Forum. 7(1). pp. 97-doi: 108. 10.22146/jcef.60216.

Priyom, S. N., Zawad, M. F. S., Rahman, M. A., \& Islam, M. M. 2020. Microstructure Analysis of Microbial Concrete: A Comparative Study. DUET Journal, 6. pp. 9-16.

Reinhardt, H. W., \& Jooss, M. 2003. Permeability and self-healing of cracked concrete as a function of temperature and crack width. Cem. Concr. Res., 33, pp.981-985.

Raina, S. S., Singla, Er. S., \& Batra, Dr. V. 2018.Comparative analysis of compressive strength and water absorption in bacterial concrete. International Journal of Engineering Development and Research , 6(3), pp. 281-286.

Selvan, V. A. T., \& Dharani, D. 2016. An experimental investigation of bacterial concrete incorporated with bacillus cereus. IJDR 6(11):10042-10045.

Silva, F. 2015. Up-Scaling the Production of Bacteria for Self-Healing Concrete Application. PhD Thesis, Ghent University.

Soleimani, S., Ormeci, B., \& Isgor, O.B. 2013. Growth and characterization of Escherichia coli DH5 $\alpha$ biofilm on concrete surfaces as a protective layer against microbiologically influenced concrete deterioration (MICD). Appl 
Microbiol Biotechnol, 97(3), pp. 1093-102. doi: 10.1007/s00253-012-4379-3.

Sreenivasulu, B., Lingamgunta, L.K., Kannali, J., Gajula, S.K., Bandikari, R., Dasari, S., Dalavai, V., Chinthala, P., Gundala, P.B., Kutagolla, P., \& Balaji, V.K. 2018. Subsurface endospore-forming bacteria possess biosealant properties. Scientific Reports. 8. doi: 10.1038/s41598-018-24730-3.

Stooks-Fischer, S., Galinat, J. K., \& Bang, S. S. 1999. Microbiological precipitation of $\mathrm{CaCO}_{3}$, Soil Biology Biochemistry. 31 (11), pp. 1563-1571.

Thakur, A., \& Singh, K. 2017. Bacterial concrete and effect of different bacteria on the strength and water absorption characteristics of concrete: A review. 10.13140/RG.2.2.15736.75525.

Tittelboom, K. V., Belie, N. D., Muynck, W. D., \& Verstraete, W. 2010. Use of bacteria to repair cracks in concrete. Cement and Concrete Research 40(1). pp. 157-166. doi: 10.1016/j.cemconres.2009.08.025.

Tziviloglou, E., Wiktor, V., Jonkers, H. M., \& Schlangen, E. 2016.Bacteria-based self-healing concrete to increase liquid tightness of cracks. Construction and Building Materials, 122, pp. 118-125.

Vijay, K., Murmu, M., \& Deo, S. 2017. Bacteria based self-healing concrete - A review. Construction and Building Materials, 152. pp. 1008-1014. 10.1016/j.conbuildmat.2017.07.040.

Wang, J., Jonkers, H. M., Boon, N., \& De Belie, N. 2017. Bacillus sphaericus LMG 22257 is physiologically suitable for self-healing concrete. Applied Microbiology and Biotechnology, 101(12), pp. 5101-5114. doi:10.1007/s00253017-8260-2.

Wang, J., Mignon, A., Snoeck, D., Wiktor, V., Boon, N. \& De Belie., N. 2015. Application of Modified-Alginate Encapsulated Carbonate Producing Bacteria in Concrete: A Promising Strategy for Crack Self-Healing. Frontiers in Microbiology. 6. pp. 1-14.
Wang, J. Y., Snoeck, D., Van Vlierberghe, S., Verstraete, W., \& De Belie, N. 2014. Application of hydrogel encapsulated carbonate precipitating bacteria for approaching a realistic self-healing in concrete. Construction and Building Materials, 68, pp. 110-119. doi: 10.1016/j.conbuildmat.2014.06.018.

Wang, J.Y., Soens, H., Verstraete, W., \& De Belie, N. 2014. Selfhealing concrete by use of microencapsulated bacterial spores. Cement and Concrete Research. Vol. 56, pp. 139-152.

Wiktor, V. \& Jonkers, H. M. 2015. Field performance of bacteria-based repair system: Pilot study in a parking garage. Case Stud. Constr. Mater., 2, pp. 11-17.

Xu, J., \& Wang, X. 2018. Self-healing of concrete cracks by use of bacteria-containing low alkali cementitious material. Construction and Building Materials. 167. pp. 1-14.

Xu, J., Wang, X., Zuo, J., \& Liu, X. 2018. SelfHealing of concrete cracks by ceramsite-loaded microorganisms. Advance in Materials Science and Engineering. doi: 10.1155/2018/5153041.

Yoon, H.-S., Yang, K.-H., \& Lee, S.-S. 2019. Evaluation of sulfuric acid resistance of biomimetic coating mortars for concrete surface protection. Journal of the Korea Concrete Institute. 31, pp. 61-68. doi: 10.4334/JKCI.2019.31.1.061.

Zhang, Y., Guo, H. X., \& Cheng, X. H. 2015. Role of calcium sources in the strength and microstructure of microbial mortar. Construction and Building Materials, 77, pp.160-167.

Zhang, X., \& Qian, C. 2020. Engineering application of microbial self-healing concrete in lock channel wall. Case Studies in Construction Materials. doi: 10.1016/j.cscm.2020.e00398.

Zulfikar, R., Putra, H., Yasuhara, H. 2021. The Utilization of Soybean as a Catalyst Material in Enzyme-Mediated Calcite Precipitation (EMCP) for Crack Healing Concrete. Journal of the Civil Engineering Forum. 7 (1). pp. 59-70. 